\title{
Incógnitas sobre el desfibrilador automático implantable.
}

Tesis doctoral Ciencias de la Salud-Medicina.

Fecha:

Doctorando: Ignacio Roy Añón.

Directora de tesis: Dra. Nuria Basterra Sola. Codirectora: Dra. Natalia López

Andrés.

Tutor: Dr. Gregorio Tiberio López.

Departamento: Ciencias de la Salud 


\section{Agradecimientos:}

Quiero expresar toda mi gratitud a mi familia, por estar siempre presentes y ser apoyo en los momentos buenos y malos. En especial a mi esposa Leire, a mis hijas Paula y Julia, a mis padres Emilio y Julia, a mi hermano Jose Mari y a mis suegros Yolanda y Paco.

De igual manera, agradezco a mis directoras de tesis, la Dra. Nuria Basterra y la Dra. Natalia López por toda la ayuda prestada durante estos años. En ocasiones el camino ha sido espinoso. Sin su apoyo y colaboración la presente investigación no hubiese salido adelante.

A mi "familia" del Área Clínica del Corazón del Complejo Hospitalario de Navarra, por su afecto y valiosas enseñanzas, no solo a nivel médico, sino también en el terreo humano.

Al resto de colaboradores en la presente investigación pertenecientes a otros Centros Clínicos y de Investigación. Por su generosidad e implicación personal con la Ciencia.

A Arkaitz Galbete, de la Unidad de Metodología del Centro de Investigación Navarrabiomed, por sus inestimables consejos y enseñanzas.

A la Escuela de Doctorado de la Universidad Pública de Navarra por su sustento académico. En particular, me gustaría reconocer al Dr. Ignacio Encío y al Dr. Gregorio Tiberio su esfuerzo y dedicación personal.

Finalmente quiero expresar mi más grande y sincero agradecimiento a toda aquella persona que a lo largo de mi vida, tanto en el ámbito académico, como extra académico, me ha enseñado y aconsejado sabiamente. 
La presente tesis doctoral es un compendio de trabajos publicados o aceptados para su publicación. Las referencias completas de los artículos que constituyen el cuerpo de la tesis son las siguientes:

1. Ignacio Roy, Javier Martínez, Luisa Pérez, José B. Martínez-Ferrer, Xavier Viñolas, Joaquín Fernández de la Concha, Roger Villuendas, Javier Alzueta, Aníbal Rodríguez, Nuria Basterra. Trends in the implantation of single-coil vs dual-coil defibrillator leads. Data from a large Spanish cohort. REC CardioClinics. 2019; 55:30-37.

DOI: $10.1016 /$ j.rccl.2019.10.003.

2. Ignacio Roy, Lorena Malagón, Javier Martínez, Javier Romero, Aitziber Munárriz, Nuria Basterra. Cancer and ICD. Causality, confusion or causality? Medicina Clínica (Ref. MEDCLI-D-20-00351R1).

Aceptado para su publicación (aún no publicado). Se adjunta carta de aceptación (apéndice). 


\section{Introducción:}

El corazón es un órgano complejo que tiene como función final el envío de sangre al organismo a través del sistema circulatorio. Dicha función de bomba hidráulica, requiere de la correcta contracción de miocardio. Para que la contracción del corazón se produzca de forma coordinada, el corazón dispone de un sistema eléctrico que distribuye de forma rápida y eficaz un impulso eléctrico que genera un cambio en la polaridad de las células cardiacas o miocitos y como consecuencia de ello su contracción. Cuando el impulso eléctrico tiene un origen o una distribución anómala se produce una arritmia. Las arritmias tienen repercusión sobre la función del corazón. Tanto es así que, en ocasiones, pueden llegar a generar un colapso circulatorio y la muerte del paciente.

Las enfermedades cardiovasculares causan en todo el mundo aproximadamente 17 millones de muertes al año, de las que aproximadamente un $25 \%$ acontecen súbitamente ${ }^{1-2}$.

La muerte súbita (MS) se define como aquella muerte presenciada, no traumática, repentina e inesperada, que sucede en la primera hora del inicio de los síntomas, en un sujeto aparentemente sano $^{3}$. En el caso de que el fallecimiento no sea presenciado, también se incluiría a personas que fueron vistas en las 24 horas previas y estaban aparentemente sanas ${ }^{3-4}$.

La muerte súbita cardiaca (MSC), es aquella MS que tiene lugar en uno de los tres siguientes supuestos $^{3-4}$ :

- Se da en un paciente que en vida presentaba una cardiopatía congénita o adquirida.

- La autopsia del paciente confirma un origen cardiovascular.

- La autopsia del paciente no rebela alteraciones estructurales (cardiacas o extracardiacas) que justifiquen el fallecimiento y se asume un origen arrítmico.

En cuanto al origen de la MSC, se distinguen dos mecanismos fundamentales. Por un lado, el origen arrítmico (arritmias ventriculares, bradiarritmias) ${ }^{5-7}$ y el origen mecánico (existirá actividad eléctrica cardiaca organizada, pero esta no genera pulso $)^{8-10}$.

En la literatura la información sobre MS es difícil de analizar por la heterogeneidad existente entre las definiciones utilizadas, la procedencia e interpretación de los datos ${ }^{3-4}$. No obstante, la prevalencia de enfermedad cardiovascular se asocia proporcionalmente con la incidencia de MSC es de cada población ${ }^{3}$. En este sentido, países como España, con menor prevalencia de enfermedad cardiovascular, tienen a su vez menor incidencia de MSC que otros países como Estados Unidos de América o Países de Norte de Europa donde la enfermedad cardiovascular es más prevalente y la 
MSC es más incidente ${ }^{11-15}$.

De todas las MS, las de origen cardiaco se estima representan un $80 \%{ }^{14}$. Aunque una MSC puede tener lugar en cualquier momento de la vida, existen dos picos con una mayor incidencia. Por un lado, aquella que tiene lugar en lactantes (entre 0-6 meses) y aquella que sucede en adultos (entre 45 y 75 años $)^{11}$. Globalmente es más frecuente en varones, especialmente en edades intermedias de la $v_{i d a}{ }^{15}$. En ancianos la incidencia es igualmente mayor en hombres, pero con diferencias menores entre ambos $\operatorname{sexos}^{15}$. Globalmente la mayor parte de los casos suceden en la población en general, en personas a priori de bajo riesgo ${ }^{16-18}$. En pacientes con factores de riesgo (cardiopatía isquémica, factores de riesgo cardiovascular, etc), aunque el número de muertes en conjunto es menor, presentan una incidencia que es mayor ${ }^{16-18}$.

En la prevención de la muerte súbita se pueden distinguir dos fases o etapas diferentes:

- Prevención primaria: se refiere a medidas encaminadas a prevenir MSC en pacientes que aún no la han sufrido, pero que se encuentran en riesgo de sufrirla.

La primera medida en este sentido, afecta a la población en su conjunto e implica la prevención y tratamiento de la enfermedad cardiovascular ${ }^{19-23}$. Abarca la realización de ejercicio físico de forma regular, mantener una dieta equilibrada que permita mantener un peso apropiado, abandonar el tabaco y detectar y tratar patologías como la hipertensión arterial, dislipemia y diabetes mellitus.

Una segunda acción igualmente enfocada a la población incluye la educación de las personas para que consulten de forma precoz ante la presencia de determinados síntomas de alarma como el dolor torácico o el síncope.

Otras medidas, en este caso dirigidas a pacientes afectos por una cardiopatía que confiera mayor riesgo de MSC, incluyen el correcto tratamiento farmacológico de su cardiopatía y la correcta y periódica estratificación del riesgo de MSC con el fin de seleccionar pacientes que puedan beneficiarse de la implantación de un desfibrilador automático implantable (DAI) ${ }^{3.4}$. Por último, existe una última medida, que no se encuentra encaminada a prevenir el desarrollo de MSC, sino a mejorar las consecuencias derivadas de esta, mediante la rápida y eficaz administración de reanimación cardiopulmonar por personas ajenas al ámbito sanitario. Para ello desde hace unos años se están realizando campañas de educación en reanimación cardiopulmonar en Centros Educativos y Empresas ${ }^{24}$.

- Prevención secundaria: son aquellas acciones encaminadas a disminuir el riesgo y las consecuencias de nuevos episodios de MSC en pacientes que ya los han sufrido y que se han recuperado. 
En este sentido, el adecuado y optimizado tratamiento farmacológico de la cardiopatía subyacente y evitar posibles desencadenantes cobran un papel capital. No obstante, la piedra angular en prevención secundaria es la implantación de un $\mathrm{DAI}^{3-4,34-37}$.

Las medidas de prevención primaria y secundaria previamente relatadas, son fruto de investigaciones desarrolladas a lo largo de las últimas décadas, ante el gran impacto que supone por tanto una MSC y en concreto aquellas con un origen arrítmico ${ }^{1-2,8}$. A continuación se describe de forma sucinta qué es un DAI, cómo ha sido su desarrollo, cuáles son los elementos que lo conforman, cuales son su funciones e indicaciones en la práctica clínica.

A mediados del siglo XX surge una tecnología que permitía tratar arritmias cardiacas mediante la administración de corriente eléctrica continua sobre el corazón, provocando el cambio simultáneo de la polaridad de los miocitos, que retorna el ritmo eléctrico del corazón a la normalidad. Dichos dispositivos se conocen como desfibriladores. Dicha tecnología supuso un importante cambio para la Medicina y más en concreto en la supervivencia de pacientes afectos por cardiopatías ${ }^{25}$.

Con los años los desfibriladores se han ido sofisticando hasta desarrollarse dispositivos que se implantan en el interior del cuerpo del paciente y que tienen capacidad de dar respuestas automáticas. Se conocen como desfibriladores automáticos implantables. El primer implante en humanos lo lleva a cabo el equipo del Dr. Mirowski en el año $1980^{26}$. Desde ese momento se ha convertido en una de las principales herramientas terapéuticas para pacientes que padecen o que tienen una probabilidad elevada para padecer arritmias cardiacas malignas, tal y como recogen distintos documentos científicos y guías de práctica clínica ${ }^{3.4}$.

Un DAI se compone de dos elementos fundamentales:

a) Generador: contiene una serie de componentes electrónicos (microprocesador, batería, condensadores, etc) rodeados por una carcasa metálica. La batería alimenta el microprocesador que analiza el ritmo cardiaco de forma continua, siendo capaz de generar respuestas automáticas en base a determinados algoritmos complejos (inhibición, administración de terapias anti-bradicardia y anti-taquicardia). Asimismo, la batería suministra energía eléctrica a unos condensadores que la acumulan, para en última instancia transmitirla al miocardio durante la desfibrilación.

b) Electrodos: son el componente que conecta el generador con el miocardio de forma bidireccional, permitiendo la lectura continua de la actividad eléctrica del corazón (sensado) y el envío de una energía eléctrica como respuesta (estimulación y desfibrilación). 
Antiguamente los electrodos se situaban en la superficie externa del corazón (epicárdico), pero con la introducción de la desfibrilación bifásica se ha logrado además una implantación en el interior del corazón (endocárdico).

Los electrodos, son probablemente la parte más susceptible del desfibrilador y con frecuencia pueden sufrir averías (fractura del conductor, alteración del recubrimiento aislante, etc) 27-28 $^{2}$ Cuando esto sucede, es preciso sustituir el electrodo dañado. La extracción de electrodos es un procedimiento complejo y no exento de complicaciones graves ${ }^{29-30}$. Por ello con frecuencia se abandona el electrodo dañado en su posición y se añade otro nuevo.

Los cables se fijan al endocardio de distintas formas: activa (hélice retráctil que permite fijar el electrodo) o pasiva (patillas de silicona que quedan ancladas en trabéculas musculares). Esta fijación evita el desplazamiento inicial de la porción distal del electrodo, ya que, pasado un tiempo, los electrodos quedarán fijos al endocardio como resultado de la fibrosis y la inflamación crónica.

Otro componente importante de un electrodo de desfibrilación son las bobinas. Estas van a ser las zonas encargadas de transmitir la energía al endocardio. Existen dos tipos de electrodo en función del número de bobinas. Los electrodos con una bobina o monobina y los electrodos con dos bobinas o bibobina. En los primeros, la bobina se sitúa en la zona distal del electrodo que se ubicará en el ápex del ventrículo derecho. En los segundos, la bobina distal se sitúa como en el anterior en la zona distal del electrodo (ventrículo derecho) y la proximal se sitúa en la zona media (zona de unión de la aurícula derecha con la vena cava superior).

Desde el punto de vista de la composición de materiales, los DAI fundamentalmente se conforman por distintos materiales plásticos y metálicos ${ }^{31-33}$. Algunos de estos materiales están en contacto con la sangre o tejidos del paciente: poliuretano (80A), poliuretano (75D), silicona (MDX-70), silicona (ETR-50), adhesivo médico de silicona, titanio, titanio recubierto de parileno, Platino iridio, polisufona (resina de poliéster o epoxi), silicona (Med 4719), silicona (MDX-70) rellena de sulfato de bario, platino proyectado sobre tántalo, recubrimiento de nitrito de titanio y esteroides. Otros materiales no deben entrar en contacto con el paciente, salvo por rotura del aislamiento del DAI: MP35N (aleación de níquel, cobalto, cromo y molibdeno), acero inoxidable 316L, MP35N con núcleo de plata, PTFE/FEP (teflón) y poliamida.

El DAI ha ido desarrollando su tecnología y se ha ido haciendo una herramienta cotidiana en la práctica habitual. Sin embargo, como cualquier medida terapéutica, tienen efectos adversos y un precio elevado. Por ello es imprescindible realizar una selección adecuada tanto de los mejores materiales y equipos técnicos, como de los pacientes que lo vayan a recibir. 
En lo referente a los pacientes, la selección debe realizarse en base al riesgo individual y a la evidencia disponible. Durante los últimos 30 años, se han realizado diversas investigaciones dirigidas a constatar la efectividad y seguridad del DAI en distintos grupos de pacientes. A continuación, se muestra una breve revisión de la evidencia más remarcable en función de la indicación y patología cardiaca subyacente:

- Prevención secundaria: parece que en este contexto una estrategia terapéutica que incluye la implantación de un DAI aporta beneficios frente a aquella basada en el uso de fármacos $\operatorname{antiarrítmicos}^{34-37}$, especialmente en pacientes con fracción de eyección del ventrículo izquierdo menor a $35 \% 37$.

Es interesante señalar que los ensayos clínicos aleatorizados realizados ${ }^{34-36}$ incluyeron fundamentalmente pacientes con cardiopatía isquémica con infarto de miocardio previo (de los 1963 pacientes incluidos en los tres estudios, solo 292 tenían una miocardiopatía no isquémica) y disfunción ventricular (FEVI entre 32-45\%). Este detalle podría implicar una limitación en la generalización de los resultados a otro grupo de pacientes. No obstante, existen estudios y registros observacionales que apuntan hacia el beneficio del DAI en contexto de otro tipo de cardiopatías en prevención secundaria ${ }^{38,40-50}$. Por ello el DAI, tal y como recogen distintas guías de práctica clínica ${ }^{3-4,39}$, es el elemento esencial en este contexto.

- Prevención primaria: en este escenario la evidencia del beneficio aportado por DAI está menos demostrada. Por ello resulta fundamental la adecuada estratificación individualizada de los pacientes para seleccionar a aquellos con un mayor riesgo de sufrir eventos arrítmicos. En este sentido, cabe remarcarse la existencia de riesgos muy diversos entre las distintas etiologías y el estadio de la enfermedad cardiaca subyacente. El mayor grado de evidencia lo acumulan la cardiopatía isquémica ${ }^{51-59}$ y miocardiopatía dilatada de origen no isquémico ${ }^{56,60-}$ 63. En otras etiologías (miocardiopatía hipertrófica, miocardiopatía arritmogénica, canalopatías, etc) la evidencia es menor ${ }^{39,64-78}$. 


\section{Antecedentes y fundamentos de la investigación:}

El DAI se ha convertido en el tratamiento indicado en pacientes que han presentado taquiarritmias ventriculares mal toleradas o que presentan una cardiopatía que predispone a sufrirlas y así se recoge en la distintas Guías y Documentos de práctica clínica ${ }^{3-4}$.

Aunque la evidencia que sustenta la indicación de implantar un DAI en prevención primaria y secundaria es amplia ${ }^{34-38,40-50}$, continúan existiendo incógnitas y vacíos en el conocimiento. A continuación, se enumeran algunas de las controversias más destacadas surgidas los últimos años:

- Selección y estratificación de pacientes candidatos a un DAI:

- Papel la genética en la estratificación del riesgo arrítmico.

- Papel del realce tardío de gadolinio (globalmente, según su localización/distribución, extensión, etc) en resonancia magnética nuclear cardiaca en la estratificación del riesgo arrítmico.

- Valor del DAI en pacientes con enfermedad renal crónica terminal.

- Valor del DAI en pacientes con cardiopatía isquémica con FEVI conservada o intermedia.

- Selección del material a implantar: tipo de generador y electrodos:

- Tipo de electrodos de desfibrilación qué debemos implantar a nuestros pacientes (monobobina vs bibobina).

- Tipo de DAI (endocavitario vs subcutáneo).

- Programación más adecuada del DAI en cada una de las indicaciones y patologías.

- Potencial relación entre el DAI y desarrollo de neoplasias.

En este contexto clínico y con el ánimo de responder a algunas de estas incógnitas, se desarrolla la presente investigación. 


\section{3. ¿Cuestiones planteadas y relevancia?}

El presente estudio plantea dos cuestiones distintas, clínicamente relevantes sobre las que el grado de conocimiento y evidencia existentes no son sólidos. El fin último es aportar un mayor conocimiento en las materias planteadas que puede aplicarse en la práctica en beneficio de los pacientes en los que se plantee implantar un DAI o en aquellos que ya son portadores.

A continuación, se especifican los apartados de la investigación. En cada uno de ellos se ha seguido el siguiente esquema de redacción: título, introducción, objetivos, metodología, resultados y conclusiones:

1) Estudio sobre electrodos de desfibrilación:

- Título: Evolución temporal en la implantación de electrodos de desfibrilación monobobina o bibobina en nuestro país. Datos de un gran registro español.

- Introducción y objetivos: En España no se dispone de datos sobre la implantación de electrodos de desfibrilación. En la literatura internacional se describe que la implantación de electrodos bibobina ha sido la predominante en la práctica clínica habitual durante los últimos veinte años. Dicha práctica se sustentaba en escasos estudios que sugerían una mejoría en el umbral de desfibrilación con dichos electrodos. Sin embargo, no se ha encontrado un verdadero beneficio clínico en términos de efectividad de la desfibrilación o de disminución de mortalidad. Además, hay que tener en cuenta varios potenciales inconvenientes de los electrodos bibobina. Por todo ello, desde hace unos años, en otros países parece estar cambiando la tendencia en favor de una mayor implantación de electrodos monobobina. Sin embargo, desconocemos lo acontecido en nuestro país.

El objetivo primario del estudio es analizar cómo ha sido la implantación de electrodos de desfibrilación durante los últimos años en nuestro país y ver si también se está produciendo algún cambio en la práctica clínica. El objetivo secundario busca identificar diferencias entre ambos tipos de electrodos que a su vez pudiesen justificar la forma en cómo se implantan los dispositivos.

- Metodología: estudio de cohortes retrospectivo de pacientes españoles portadores de desfibrilador, incluidos consecutivamente en el Registro multicéntrico UMBRELLA y seguidos remotamente mediante sistema Carelink ${ }^{\circledR}$, entre 2005 y 2016. Participaron 44 Centros Médicos de 12 Comunidades Autónomas Españolas.

- Resultados: se incluyeron 4131 pacientes portadores de DAI. El seguimiento medio de $752,7 \pm 798,7$ días en los monobobina y de 1444,2 $\pm 692,2$ días en los bibobina.

Entre el año 2005 y el año 2013 los electrodos bibobina eran los más implantados, siendo la proporción de los electrodos monobobina implantados menor al 10\%. Sin embargo, 
desde el año 2014, la proporción de electrodos monobobina implantados ha ido aumentando progresivamente, hasta ser los más implantados en el año 2016 (51.8\% vs $48.2 \%)$.

En cuanto a las complicaciones acaecidas durante el implante del dispositivo o durante el seguimiento, no observamos diferencias significativas entre ambos tipos de electrodos, más allá de una mayor proporción de choques en el grupo bibobina $(17.5 \%$ vs $5.8 \%$, $\mathrm{P}<0.001$ ), estando dicho hallazgo probablemente muy influido por el menor tiempo de seguimiento acumulado en desfibriladores monobobina y con las antiguas y más agresivas programaciones de los desfibriladores.

- Conclusiones: La práctica clínica con desfibriladores ha ido cambiando tanto en la forma de implantar como en la forma de programar los dispositivos. En lo que a electrodos de desfibrilación se refiere, en nuestro registro observamos un cambio en la elección del tipo de electrodo de desfibrilación, siendo los electrodos monobobina los implantados con más frecuencia en los últimos años.

2) Estudio sobre la potencial relación entre el desarrollo de cáncer y el DAI:

- Título del artículo publicado en una revista indexada o comunicado en un congreso: Cáncer y desfibrilador automático implantable ¿causalidad, confusión o casualidad?

- Introducción y objetivos: el desfibrilador automático implantable (DAI) se ha establecido como terapia en pacientes con elevado riesgo de sufrir arritmias ventriculares malignas. Algunos estudios plantean un posible efecto oncogénico de materiales protésicos utilizados. Igualmente, existen trabajos que describen mayor incidencia de cáncer en portadores de DAI y plantean una potencial relación causal entre ambos.

El objetivo principal del estudio es describir la incidencia de cáncer en nuestra muestra de pacientes portadores de DAI y compararla con resultados de otras bases de datos.

- Métodos: estudio de cohortes retrospectivo de pacientes con DAI que se incluyeron en el Complejo Hospitalario de Navarra entre los años 2000 y 2016 y se siguieron hasta junio de 2018 .

Se analizaron variables sociodemográficas, comorbilidades y datos sobre patología oncológica.

Se estimaron tasas de incidencia acumulada (TIA) de cáncer durante el seguimiento que se compararon con datos poblacionales y con datos de otra cohorte de pacientes con insuficiencia cardiaca con FEVI reducida. Se ajustaron modelos de riesgos competitivos para cáncer en el seguimiento.

- Resultados: se incluyeron 497 pacientes, mayoritariamente hombres $(89.1 \%)$ con una edad 
media 59.98 (14.98) años, con una proporción de fumadores del 67.6\% y de cardiopatía isquémica del $51.6 \%$. La TIA de cáncer fue 1230.9 por 100.000 personas-año. Las variables que se asociaron significativamente con cáncer fueron mayor edad, mayor consumo de tabaco y cardiopatía isquémica.

- Conclusiones: la incidencia de cáncer es elevada en pacientes con DAI. Este hallazgo parece relacionado principalmente con el tabaco y la mayor edad. 


\section{Síntesis de las aportaciones de la Tesis:}

A continuación, se describen brevemente las aportaciones y novedades más destacables de cada uno de las investigaciones que componen la tesis:

1. Evolución temporal en la implantación de electrodos de desfibrilación monobobina o bibobina en nuestro país. Datos de un gran registro español.

- Por primera vez disponemos de datos sobre la implantación de electrodos de desfibrilación en nuestro país.

- Se observa un cambio en la forma de implantar los electrodos de desfibrilación, siendo más frecuente el uso de electrodos monobobina durante los últimos años.

- No se observaron diferencias clínicamente relevantes entre un tipo u otro de electrodo de desfibrilación. Este hecho puede favorecer la predilección acaecida los últimos años por los electrodos monobobina, atendiendo fundamentalmente al mayor riesgo potencial durante la extracción de los electrodos bibobina.

- Los hallazgos previamente descritos son novedosos en nuestro país. Son a su vez concordantes con lo descrito en la literatura internacional.

2. Cáncer y desfibrilador automático implantable ¿causalidad, confusión o casualidad?

- Se objetiva una mayor tasa de incidencia acumulada de cáncer en los pacientes portadores de un DAI en comparación con la población general. Sin embargo, dicha tasa es similar a la descrita en pacientes con insuficiencia cardiaca con FEVI reducida y que mayoritariamente no portan un DAI.

- En el análisis estratificado de la muestra por edad, tabaquismo o presencia de cardiopatía isquémica observamos como la tasa de incidencia de cáncer en pacientes jóvenes, no fumadores y sin cardiopatía isquémica, se reduce hasta acercarse a valores semejantes a las poblacionales.

- En resumen, parece plausible que los principales factores de riesgo para el desarrollo de cáncer en esta población sean la mayor edad y el tabaquismo y no los desfibriladores. 


\section{Bibliografía:}

1. Niemeijer MN, Van de Berg ME, Leening MJ, et al. Declining incidence of sudden cardia death from 1990-2010 in a general middle-aged and elderly population: The Rotterdam Study. Heart Rhythm. 2015; 12:123-129.

2. Mendis SPP, Norving B. Global atlas on cardiovascular disease prevention and control Geneva: World Health Organization, 2011.

3. Priori SG, Blomstrom-Lundqvist C, Mazzanti A, et al. 2015 ESC Guidelines for the management of patients with ventricular arrhythmias and the prevention of sudden cardiac death: The Task Force for the Management of Patients with Ventricular Arrhythmias and the Prevention of Sudden Cardiac Death of the European Society of Cardiology (ESC) Endorsed by: Association for European Paediatric and Congenital Cardiology (AEPC). Eur Heart J. 2015; 36: 2793-2867.

4. Zipes DP, Camm AJ, Borggrefe M, et al. ACC/AHA/ESC 2006 guidelines for management of patients with ventricular arrhythmias and the prevention of sudden cardiac death-executive summary: A report of the American College of Cardiology/American Heart Association Task Force and the European Society of Cardiology Committee for Practice Guidelines (Writing Committee to Develop Guidelines for Management of Patients with Ventricular Arrhythmias and the Prevention of Sudden Cardiac Death) Developed in collaboration with the European Heart Rhythm Association and the Heart Rhythm Society. Eur Heart J. 2006; 27:2099-2140.

5. Bayes de Luna A, Coumel P, Leclercq JF. Ambulatory sudden cardiac death: mechanisms of production of fatal arrhythmia on the basis of data from 157 cases. Am Heart J. 1989; 117:151159.

6. Dubner SJ, Pinski S, Palma S, et al. Ambulatory electrocardiographic findings in out-of-hospital cardiac arrest secondary coronary artery disease. Am J Cardiol. 1989; 64:801-806.

7. Wood MA, Stambler BS, Damiano RJ, et al. Lessons learned from data logging in a multicenter clinical trial using a late-generation implantable cardioverter-defibrillator. The Guardian ATP 4210 Multicenter Investigators Group. J Am Coll Cardiol. 1994; 24:1692-1699.

8. Cummins RO, Ornato JP, Thies WH, et al. Improving survival from sudden cardiac arrest: the "chain of survival" concept. A statement for health professionals from the Advanced Cardiac Life Support Subcommittee and the Emergency Cardiac Care Committee, American Heart Association. Circulation. 1991; 83:1832-1847.

9. Tovar OH, Jones JL. Electrophysiological Deterioration During Long-Duration Ventricular Fibrillation. Circulation. 2000; 102:2886-2891.

10. Kurkciyan I, Meron G, Sterz F, et al. Pulmonary embolism as a cause of cardiac arrest: presentation and outcome. Arch Inter Med. 2000; 160:1529-1535. 
11. Marrugat J, Elosua R, Gil M. Epidemiology of sudden cardiac death in spain. Rev Esp Cardiol. $1999 ; 52: 717-725$.

12. Morentin B, Audicana C. Population-based study of out-of-hospital sudden cardiovascular death: incidence and causes of death in middle-aged adults. Rev Esp Cardiol. 2011; 64:28-34.

13. Byrne R, Constant O, Smyth Y, et al. Multiple source surveillance incidence and aetiology of outhospital sudden cardiac death in a rural population in the West of Ireland. Eur Heart J. 2008; 29:1418-1423.

14. Chug SS, Jui J, Gunson K, et al. Current burden of sudden cardiac death: multiple source surveillance versus retrospective death certificate-based review in a large U.S. Community. J Am Coll Cardiol. 2004; 44:1268-1275.

15. Kuller L, Lilienfeld A, Fisher R. An epidemiological study of sudden and unexpected deaths in adults. Medicine (Baltimore). 1967; 46:341-361.

16. Myerburg RJ. Sudden cardiac death: exploring the limits of our Knowledge. J Cardiovasc Electrophysiol. 2001; 12:369-381.

17. Myerburg RJ, Mitrani R, Interian A, Jr., et al. Interpretation of outcomes of antiarrhythmic clinical trials: design features and population impact. Circulation. 1998; 97:1514-1521.

18. Myeburg RJ, Interian A, Jr., Mitratin RM, et al. Frequency of sudden cardiac death and profiles of risk. Am J Cardiol. 1997; 80:10F-19F.

19. Chow CK, Jolly S, Rao-Melacini P, Fox KA, Anand SS, Yusuf S. Association of diet, exercise, and smoking modification with risk of early cardiovascular events after acute coronary syndromes. Circulation. 2010; 121:750-758.

20. Booth III JN, Levitan EB, Brown TM, Farkouh ME, Safford MM, Muntner P. Effect of sustaining lifestyle modifications (nonsmoking, weight reduction, physical activity, and Mediterranean diet) after healing of myocardial infarction, percutaneous intervention, or coronary bypass (from the Reasons for Geographic and Racial Differences in Stroke Study). Am J Cardiol. 2014; 113:19331940.

21. Giannuzzi P, Temporelli PL, Marchioli R, Maggioni AP, Balestroni G, Ceci V, Chieffo C, Gattone M, Griffo R, Schweiger C, Tavazzi L, Urbinati S, Valagussa F, Vanuzzo D. GOSPEL Investigators Global secondary prevention strategies to limit event recurrence after myocardial infarction: results of the GOSPEL study a multicenter randomized controlled trial from the Italian Cardiac Rehabilitation Network Arch Intern Med. 2008; 168:2194-2204.

22. Keteyian SJ, Brawner CA, Savage PD, Ehrman JK, Schairer J, Divine G, Aldred H, Ophaug K, Ades PA. Peak aerobic capacity predicts prognosis in patients with coronary heart disease. Am Heart J. 2008; 156:292-300. 
23. Critchley JA, Capewell S. Mortality risk reduction associated with smoking cessation in patients with coronary heart disease: a systematic review. JAMA. 2003; 290:86-97.

24. Travers AH, Perkins GD, Berg RA, et al. Part 3: adult basic life support and automated external defibrillation: 2015 International Consensus on Cardiopulmonary Resuscitation and Emergency Cardiovascular Care Science with Treatment Recommendations. Circulation. 2015; 132:S51-83.

25. Deyell M, Tung S, Ignaszewski A. The implantable cardioverter-defibrillator: from Mirowski to its current use. BCMJ. 2010; 52:248-253.

26. Mirowski M, Reid PR, Mower MM, et al. Termination of malignant ventricular arrhythmias with an implanted automatic defibrillator in human beings. N Engl J Med. 1980; 303:322-324.

27. Dorwarth U, Frey B, Dugas M, et al. Transvenous defibrillation leads: high incidence of failure during long-term follow-up. J Cardiovasc Electrophysiol. 2003; 14:38-43.

28. Kleemann T, Becker T, Doenges K, et al. Annual rate of trans-venous defibrillation lead defects in implantable cardioverter-defibrillators over a period of $>10$ years. Circulation. 2007; 115:24742480.

29. Gould PA, Krahn AD. Complications associated with implantable cardioverter-defibrillator replacement in response to device advisories. JAMA. 2006; 295:1907-11.

30. F. Bracke. Complications and lead extraction in cardiac pacing and defibrillation. Neth Heart J. 2008; 16:S28-S31.

31. https://www.medtronic.com/content/dam/medtroniccom/01_crhf/tachy/documents/201602643ENp6\%20Visia\%20AF\%20VR\%20DVAB1D4.pdf

32. http://manuals.medtronic.com/content/dam/emanuals/crdm/M220682A002_CONT_20080123.p df

33. https://www.bostonscientific.com/content/dam/bostonscientific/Rhythm\%20Management/portfo lio-group/EMBLEM_S-ICD/Download_Center/CRM-385801AA\%20APR2016\%20EMBLEM\%20MRI\%20spec\%20sheet_english.pdf

34. Kuck KH, Cappato R, Siebels J, et al. Randomized comparison of antiarrhythmic drug therapy with implantable defibrillators in patients resuscitated from cardiac arrest: The Cardiac Arrest Study Hamburg (CASH). Circulation. 2000; 102:748-754.

35. The Antiarrhythmics Versus Implantable Defibrillators (AVID) Investigators. A comparison of antiarrhythmic-drug therapy with implantable defibrillators in patients resuscitated from nearfatal ventricular arrhythmias. N Engl J Med. 1997; 337:1576-1583.

36. Connolly SJ, Gent M, Roberts RS, et al. Canadian implantable defibrillator study (CIDS): A randomized trial of the implantable cardioverter defibrillator against amiodarone. Circulation. 2000; 101:1297-1302. 
37. Connolly SJ, Hallstrom AP, Cappato R, et al. Meta-analysis of the implantable cardioverter defibrillator secondary prevention trials. European Heart Journal. 2000; 21:2071-2078.

38. O'Mahony C, Lambiase PD, Quarta G, et al. The long-term survival and the risk and benefits of implantable cardioverter defibrillators in patients with hypertrophic cardiomyopathy. Heart. 2012; 98:116-125.

39. Elliot PM, Anastasakis A, Borger MA, et al. 2014 ESC Guidelines on diagnosis and management of hypertrophic cardiopathy: The Task Force for the diagnosis and management of hypertrophic cardiopathy of the European Society of Cardiology (ESC). Eur Heart J. 2014; 35:2733-2779.

40. Schinckel AF. Implantable cardioverter defibrillators in arrhythmogenic right ventricular dysplasia/cardiomyopathy: patients outcomes, incidence of appropriate and inappropriate interventions, and complications. Circ Arrhytm Electrophysiol. 2013; 6:562-568.

41. Muratore CA, Batista Sa LA, Chiale PA, et al. Implantable cardioverter defibrillators and Chagas' disease: results of the ICD Registry Latin America. Europace. 2009; 11:164-168.

42. Martinelli M, de Siqueira SF, Sternick EB, et al. Long-term follow-up of implantable cardioverterdefibrillator for secondary prevention in Chagas heart disease. Am J Cardiol. 2012; 110:10401045.

43. Gali WL, Sarabanda AV, Baggioñ JM, et al. Implantable cardioverter-defibrillators for treatment of sustained ventricular arrhythmias in patients with Chagas' heart disease: comparison with a control group treated with amiodarone alone. Europace. 2014; 16:674-680.

44. Moss AJ, ZarebaW, Hall WJ, et al. Effectiveness and limitations of beta-blocker therapy in congenital long-QT syndrome. Circulation. 2000; 101:616-623.

45. Zareba W, Moss AJ, Daubert JP, et al. Implantable cardioverter defibrillator in high-risk long QT syndrome patients. J Cardiovasc Electrophysiol. 2003; 14:337-341.

46. Schwartz PJ, Spazzolini C, Priori SG, et al. Who are the long-QT syndrome patients who receive an implantable cardioverter defibrillator and what happens to them? data from the European Long-QT Syndrome Implantable Cardioverter-Defibrillator (LQTS ICD) Registry. Circulation. $2010 ; 122: 1272-1282$.

47. Jons C, Moss AJ, Goldenberg I, Liu J, McNitt S, ZarebaW, Qi M, Robinson JL. Risk of fatal arrhythmic events in long QT syndrome patients after syncope. J Am Coll Cardiol. 2010; 55:783788.

48. Priori SG, Napolitano C, Gasparini M, et al. Natural history of Brugada syndrome: insights for risk stratification and management. Circulation. 2002; 105:1342-1347.

49. Priori SG, Napolitano C, Memmi M, et al. Clinical and molecular characterization of patients with catecholaminergic polymorphic ventricular tachycardia. Circulation. 2002; 106:69-74. 
50. Moss AJ, Jaskson Hall W, Cannom DS, et al. Improved survival with an implanted defibrillator in patients with coronary disease at high risk for ventricular arrhythmia. N Engl J Med. 1996; 335:1933-1944.

51. Bigger JT, JR, et al. Prophylactic use of implanted cardiac defibrillators in patients at high risk for ventricular arrhythmias after coronary-artery bypass graft surgery. N Engl J Med. 1997; $337: 1569-1575$.

52. Buxton AE, Lee KL, DiCarlo L, et al. Electrophysiologic testing to identify patients with coronary artery disease who are at risk for sudden death. Multicenter Unsustained Tachycardia Trial Investigators. N Engl J Med. 2000; 342:1937-1945.

53. Moss AJ, Zareba W, Hall WJ, et al. Prophylactic implantation of a defibrillator in patients with myocardial infarction and reduced ejection fraction. N Engl J Med. 2002; 346:877-883.

54. Hohnloser SH, Heinz Kuck K, Dorian P, et al. Prophylactic Use of an Implantable CardioverterDefibrillator after Acute Myocardial Infarction. N Engl J Med. 2004; 351:2481-2488.

55. Bardy GH, Lee KL, Mark DB, et al. Sudden Cardiac Death in Heart Failure Trial (SCD-HeFT) Investigators. Amiodarone or an implantable cardioverter-defibrillator for congestive heart failure. N Engl J Med. 2005; 352:225-237.

56. Steinbeck G, Andresen D, Seidl K, et al. Defibrillator implantation early after myocardial infarction. N Engl J Med. 2009; 361:1427-1436.e

57. Barsheshet A, Arthur J. Moss AJ, Huang DT, et al. Applicability of a risk score for reduction of the long-term benefit of the implantable cardioverter-defibrillator. J A Coll Cardiol. 2012; 59:2075-2079.

58. Olgin JE, Pletcher MJ, Vittinghoff E, et al. Wearable Cardioverter-Defibrillator after Myocardial Infarction. N Engl J Med. 2018; 379:1205-1215.

59. Bansch D, Antz M, Boczor S, et al. Primary prevention of sudden cardiac death in idiopathic dilated cardiomyopathy: the Cardiomyopathy Trial (CAT). Circulation. 2002; 105:1453-1458.

60. Strickberger SA, Hummel JD, Bartlett TG, et al. Amiodarone versus implantable cardioverter defibrillator: randomized trial in patients with nonischemic dilated cardiomyopathy and asymptomatic nonsustained ventricular tachycardia-AMIOVIRT. J Am Coll Cardiol. 2003; 41:1707-1712.

61. Kadish A, Dyer A, Daubert JP, et al. Defibrillators in Non-Ischemic Cardiomyopathy Treatment Evaluation Investigators. Prophylactic defibrillator implantation in patients with nonischemic dilated cardiomyopathy. N Engl J Med. 2004; 350:2151-2158.

62. Køber L, Thune JJ, Nielsen JC, et al. Defibrillator Implantation in Patients with Nonischemic Systolic Heart Failure. N Engl J Med. 2018; 375:1221-1230. 
63. Corrado D, Leoni L, Link MS, et al. Implantable Cardioverter-Defibrillator Therapy for Prevention of Sudden Death in Patients With Arrhythmogenic Right Ventricular Cardiomyopathy/Dysplasia. Circulation. 2003; 108:3084-3091.

64. Roguin A, Bomma CS, Nasir K, et al. Implantable cardioverter defibrillators in patients with arrhythmogenic right ventricular dysplasia/cardiomyopathy. J Am Coll Cardiol. 2004; 43:18431852.

65. Bhonsale A, James CA, Tichnell C, et al. Incidence and predictors of implantable cardioverterdefibrillator therapy in patients with arrhythmogenic right ventricular dysplasia/cardiomyopathy undergoing implantable cardioverter defibrillator implantation for primary prevention. J Am Coll Cardiol. 2011; 58:1485-1496.

66. Schinkel AFL. Implantable Cardioverter Defibrillators in Arrhythmogenic Right Ventricular Dysplasia/Cardiomyopathy Patient Outcomes, Incidence of Appropriate and Inappropriate Interventions, and Complications. Circ Arrhythm Electrophysiol. 2013; 6:562-568.

67. Orgeron GM, Te Riele A, Tichnell C, et al. Performance of the 2015 International Task Force Consensus Statement Risk Stratification Algorithm for Implantable Cardioverter-Defibrillator Placement in Arrhythmogenic Right Ventricular Dysplasia/Cardiomyopathy. Circ Arrhythm Electrophysiol. 2018; $11: \mathrm{e} 005593$.

68. Priori SG, Schwartz PJ, Napolitano C, et al. Risk stratification in the long-QT syndrome. N Engl J Med. 2003; 348:1866-1874.

69. Jons C, Moss AJ, Goldenberg I, Liu J, et al. Risk of fatal arrhythmic events in long QT syndrome patients after syncope. J Am Coll Cardiol. 2010; 55:783-788.

70. Brugada J, Brugada R, Brugada P. Determinants of sudden cardiac death in individuals with the electrocardiographic pattern of Brugada syndrome and no previous cardiac arrest. Circulation. 2003; 108:3092-3096.

71. Priori SG, Napolitano C, Gasparini M, et al. Natural history of Brugada syndrome: insights for risk stratification and management. Circulation. 2002; 105:1342-1347.

72. Gallego P, Gonzalez AE, Sanchez-Recalde A, et al. Incidence and predictors of sudden cardiac arrest in adults with congenital heart defects repaired before adult life. Am J Cardiol. 2012; 110:109-117.

73. Ghai A, Silversides C, Harris L, et al. Left ventricular dysfunction is a risk factor for sudden cardiac death in adults late after repair of tetralogy of Fallot. J Am Coll Cardiol. 2002; 40:16751680.

74. Gatzoulis MA, Balaji S, Webber SA, et al. Risk factors for arrhythmia and sudden cardiac death late after repair of tetralogy of Fallot: a multicentre study. Lancet. 2000; 356:975-981. 
75. Khairy P, Landzberg MJ, Gatzoulis MA, et al. Value of programmed ventricular stimulation after tetralogy of fallot repair: a multicenter study. Circulation. 2004; 109:1994-2000.

76. Koyak Z, Harris L, de Groot JR, et al. Sudden cardiac death in adult congenital heart disease. Circulation. 2012; 126:1944-1954.

77. Kammeraad JA, van Deurzen CH, Sreeram N, et al. Predictors of sudden cardiac death after Mustard or Senning repair for transposition of the great arteries. J Am Coll Cardiol. 2004; 44:1095-1102. 
Copia de los trabajos publicados o aceptados para su publicación. 


\title{
REC: CardioClinics
}

\section{Artículo original}

\section{Evolución temporal en la implantación de electrodos de desfibrilación monobobina o bibobina en nuestro país. Datos de un gran registro español}

\author{
Ignacio Roy ${ }^{a, *}$, Javier Martínez ${ }^{a}$, Luisa Pérez ${ }^{b}$, José B. Martínez-Ferrer ${ }^{c}$, Xavier Viñolas $^{d}$, \\ Joaquín Fernández de la Concha ${ }^{e}$, Roger Villuendas ${ }^{f}$, Javier Alzueta ${ }^{g}$, Aníbal Rodríguez ${ }^{h}$ \\ y Nuria Basterra ${ }^{a, i}$ \\ a Área Clínica del Corazón, Cardiología, Complejo Hospitalario de Navarra, Pamplona, Navarra, España \\ b Servicio de Cardiología, Hospital Universitario de A Coruña, A Coruña, España \\ c Servicio de Cardiología, Hospital Universitario de Araba, Vitoria-Gasteiz, Álava, España \\ d Servicio de Cardiología, Hospital de la Santa Creu i Sant Pau, Barcelona, España \\ e Servicio de Cardiología, Hospital Universitario Infanta Cristina, Badajoz, España \\ f Servicio de Cardiología, Hospital Germans Trias i Pujol, Badalona, Barcelona, España \\ g Servicio de Cardiología, Hospital Universitario Hospital Virgen de la Victoria, Málaga, España \\ h Servicio de Cardiología, Hospital Universitario de Canarias, Santa Cruz de Tenerife, España \\ ${ }^{\mathrm{i}}$ Instituto de Investigación Sanitaria de Navarra (IdiSNA), Navarra, España
}

\section{INFORMACIÓN DEL ARTÍCULO}

Historia del artículo:

Recibido el 21 de agosto de 2019

Aceptado el 15 de octubre de 2019

On-line el 10 de diciembre de 2019

Palabras clave:

Desfibrilador automático

implantable

Electrodos de desfibrilación

Monobobina

Bibobina

\section{R E S U M E N}

Introducción y objetivos: En España no se dispone de datos sobre la implantación de electrodos de desfibrilación. Registros internacionales han descrito en los últimos años un cambio en favor de los electrodos monobobina. El objetivo primario de nuestro estudio fue tratar de inferir cómo ha sido la implantación de electrodos de desfibrilación durante los últimos años en nuestro país. El objetivo secundario busca identificar diferencias entre ambos tipos de electrodos.

Métodos: Se analizaron datos de 4.131 pacientes españoles portadores de un desfibrilador automático implantable, incluidos consecutivamente en el registro UMBRELLA y seguidos remotamente mediante sistema CareLink, entre 2005 y 2016.

Resultados: Inicialmente la proporción de electrodos de desfibrilación monobobina era $<10 \%$. Desde el año 2014, la proporción de electrodos monobobina implantados ha ido aumentando progresivamente, hasta superar la proporción de electrodos bibobina en el año 2016 (51,8\% frente a $48,2 \%$ ). En cuanto a las complicaciones acaecidas durante el implante del dispositivo o durante el seguimiento, no se observaron diferencias significativas entre ambos tipos de electrodos, más allá de una mayor proporción de choques en el grupo bibobina (17,5\% frente a $5,8 \% ; p<0,001$ ), estando dicho hallazgo probablemente muy influido por las antiguas y más agresivas programaciones de los desfibriladores.

\footnotetext{
* Autor para correspondencia.

Correo electrónico: iroy.md@gmail.com (I. Roy).

https://doi.org/10.1016/j.rccl.2019.10.003

2605-1532/@ 2019 Sociedad Española de Cardiología. Publicado por Elsevier España, S.L.U. Todos los derechos reservados.
} 
Conclusiones: La práctica clínica con desfibriladores ha ido cambiando tanto en la forma de implantar como en la forma de programar los dispositivos. En lo que a electrodos de desfibrilación se refiere, en nuestro registro se observó un cambio en la elección del tipo de electrodo de desfibrilación, ya que fueron los electrodos monobobina los implantados con más frecuencia en los últimos años.

๑ 2019 Sociedad Española de Cardiología. Publicado por Elsevier España, S.L.U. Todos los derechos reservados.

\section{Trends in the implantation of single-coil vs dual-coil defibrillator leads. Data from a large Spanish cohort}

\section{A B S T R A C T}

Keywords:

Implantable

cardioverter-defibrillator

Implantable defibrillation leads

Single-coil leads

Dual-coil leads
Introduction and objectives: There is no data available on the use of implantable defibrillator leads in Spain. Dual-coil defibrillator lead has been the most common lead system in clinical practice in the last twenty years. The aim of this study is to give an idea about how defibrillator leads have been implanted in Spain over a 10-year period. A Secondary objective consists on trying to identify differences between both type of leads.

Methods: We have analysed data from 4131 Spanish patients that carry an implantable cardioverter-defibrillator, that were included in the UMBRELLA trial and followed remotely with CareLink system between 2005 and 2016.

Results: Initially, the proportion of single-coil defibrillation leads was less than $10 \%$. After 2014, the proportion of single-coil leads has increased, being the most frequent type of lead in the year 2016 (51.8\% vs 48.2\%). We have not appreciated differences between both defibrillation leads beyond a higher incidence of administered shocks in dual-coil leads $(17.5 \%$ vs $5.8 \% ; p<.001)$. This observation is probably related to the way on defibrillators were programed some year ago.

Conclusions: During the last years, clinical practice with defibrillators has changed in the way devices are implanted and programed. When we analysed defibrillation lead data in our study, we observed a change in the choice of the lead type, being single-coil leads the most commonly implanted in recent years.

@ 2019 Sociedad Española de Cardiología. Published by Elsevier España, S.L.U. All rights reserved.

\section{Introducción}

En España, anualmente se publica un registro nacional sobre desfibrilador automático implantable. Dicho registro no recoge el tipo de electrodo de desfibrilación utilizado en cada implante ${ }^{1}$. Esto hace que existan escasos datos publicados acerca de la implantación de electrodos de desfibrilación y ninguno de ellos muestra una aproximación a la realidad actual en España.

En la literatura internacional se describe que la implantación de electrodos bibobina ha sido la predominante en la práctica clínica habitual durante los últimos 20 años ${ }^{2,3}$. Dicha práctica se sustentaba en escasos estudios que sugerían una mejoría en el umbral de desfibrilación ${ }^{4-7}$. Sin embargo, no se ha encontrado un verdadero beneficio clínico en términos de efectividad de la desfibrilación o de disminución de mortalidad $^{2,3}$. Además, hay que tener en cuenta varios potenciales inconvenientes de los electrodos bibobina ${ }^{3,8}$. Parece claro que existe un mayor riesgo de complicaciones en caso de necesitar su extracción. Por todo ello, desde hace unos años, parece estar cambiando la tendencia en favor de una mayor implantación de electrodos monobobina ${ }^{9-11}$.
Con el presente trabajo, en primer lugar, se busca aclarar en base a los datos de nuestro registro si la distribución en la implantación de los electrodos de desfibrilación monobobina y bibobina ha ido variando a lo largo de los últimos años, tanto de forma global (incluidos los datos de todos los centros) como por comunidades autónomas. En segundo lugar, se analizan datos clínicos de los pacientes y técnicos sobre los dispositivos que pudieran detectar diferencias entre ambos tipos de electrodos y que a su vez pudiesen justificar la forma en cómo se implantan los dispositivos.

\section{Métodos}

Se utilizaron datos provenientes del registro UMBRELLA. Se trata de un estudio español multicéntrico observacional retrospectivo patrocinado por Medtronic. Se analizaron datos de 4.131 pacientes portadores de desfibrilador automático implantable, incluidos en 44 centros distribuidos en 12 comunidades autónomas españolas, de forma consecutiva y seguidos de forma remota mediante el sistema CareLink entre septiembre de 2005 y diciembre de 2016 con un seguimiento medio de $752,7 \pm 798,7$ días en los monobobina y de $1.444,2 \pm 692,2$ días en los bibobina. 


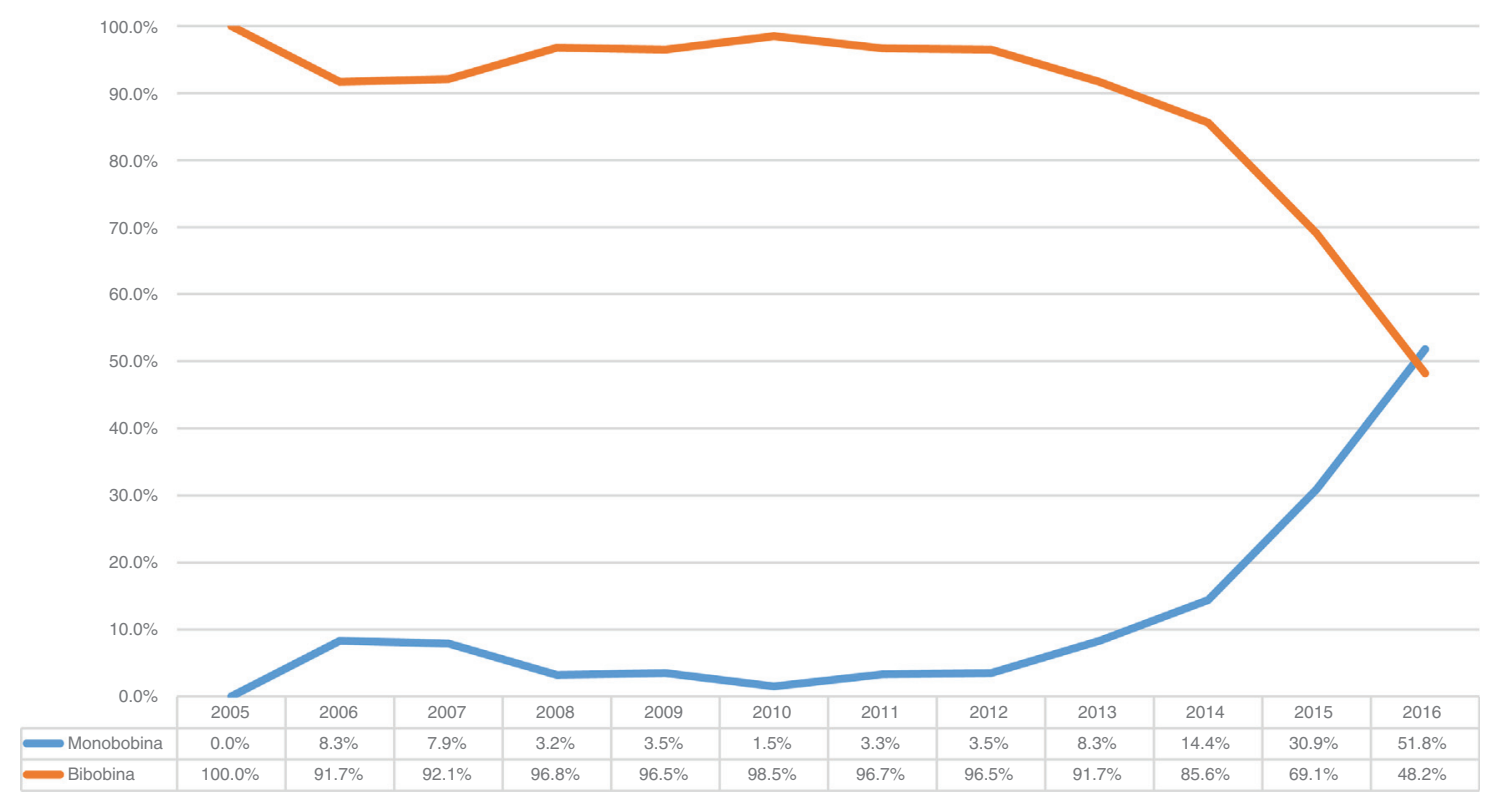

Figura 1 - Evolución temporal de la proporción de electrodos de desfibrilación monobobina (línea azul) y bibobina (línea naranja) implantados en nuestro registro durante el seguimiento.

En primer lugar, se estudió si tuvo lugar algún cambio en la tendencia de la implantación de electrodos monobobina y bibobina tanto de forma global como en las distintas regiones.

En segundo lugar, se llevó a cabo un análisis de variables clínicas de los pacientes (edad, sexo, tipo de cardiopatías, etc.) y de determinadas variables técnicas (tipo de dispositivo implantado, complicaciones acaecidas durante el implante o el seguimiento, etc.), en función del tipo de electrodo implantado, con el fin de determinar si alguna de ellas condicionaba una determinada variación en la práctica clínica.

Para llevar a cabo el análisis estadístico y elaborar tablas y gráficos se utilizó el software SPSS Estatistics v23 y Excel v2016, respectivamente. Los pacientes se distribuyeron en 2 grupos según el tipo de electrodo: bibobina o monobobina. Para la comparación de variables categóricas (proporciones), se utilizó la prueba de $\chi^{2}$ o su análogo no paramétrico (test exacto de Fisher) cuando no se pudo asumir la normalidad de la variable dependiente. Para variables ordinales, se utilizó la prueba de $\chi^{2}$ de tendencia lineal. Para la comparación de variables continuas (medias), se recurrió a ANOVA, t de Student o su análogo no paramétrico (test de Wilcoxon-Mann-Whitney) cuando no se pudo asumir la normalidad de la variable dependiente. Finalmente, los análisis multivariables se ajustaron mediante modelos basados en regresión logística.

El estudio cuenta con la debida autorización formal de los individuos, los centros participantes y del Comité Ético del Hospital Puerta de Hierro.

\section{Resultados}

Evolución temporal de la implantación de electrodos monobobina y bibobina

Globalmente, se encontró una tendencia significativa $(\mathrm{p}<0,001)$ a una mayor implantación de electrodos monobobina los últimos años. Esta tendencia se hizo especialmente evidente a partir del año 2014 (fig. 1 y línea roja discontinua de la fig. 2).

En el análisis pormenorizado por comunidades autónomas, se aprecia una tendencia similar en la mayoría de regiones, si bien el cambio es más evidente en algunas regiones como Navarra, País Vasco, Murcia, Asturias o Cataluña (fig. 2).

\section{Características basales}

Del total de pacientes $(n=4.131)$, se implantó un electrodo monobobina al 12,9\% $(n=535)$ y un electrodo bibona al $87,1 \%(\mathrm{n}=3.596)$. En la tabla 1 se detallan las características demográficas y clínicas en función del tipo de electrodo de desfibrilación implantado. Los pacientes a los que se les implantó un electrodo monobobina eran más jóvenes, con más prevalencia de enfermedad renal crónica, hipertensión arterial y valvulopatía.

\section{Predictores clínicos y técnicos de la implantación de electrodos monobobina}

A continuación, se trató de identificar variables clínicamente relevantes que se pudiesen asociar con una mayor implantación de electrodos de desfibrilación monobobina. Para ello se elaboró un modelo de análisis univariante que posteriormente se ajustó aplicando un modelo de análisis multivariante basado en una regresión logística (tabla 2). Como puede apreciarse en el análisis multivariante, una vez ajustadas por el resto de variables, determinadas variables como sexo o fracción de eyección del ventrículo izquierdo no perecieron influir en la decisión de implantar un tipo u otro de electrodo de desfibrilación. En cambio, otras sí parecen influir. Entre ellas, la mayor juventud del paciente, la presencia de 


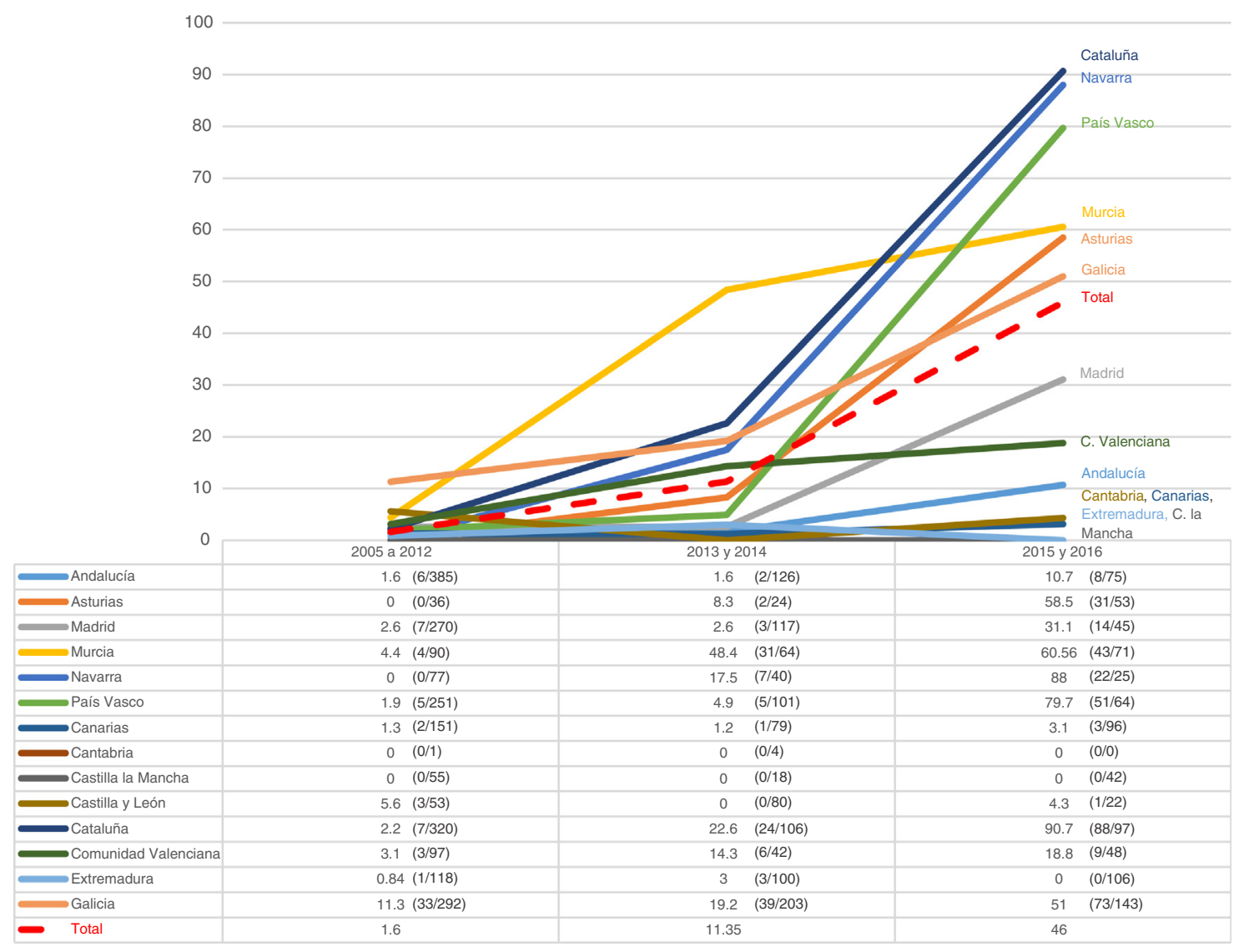

Figura 2 - Evolución temporal de la proporción de electrodos monobobina implantados durante el seguimiento, tanto de forma global (línea roja discontinua) como en las distintas comunidades autónomas. En la tabla adjunta se refleja el valor numérico de las proporciones representadas gráficamente más arriba, detallándose entre paréntesis el número de pacientes portadores de electrodos monobobina entre el total de los incluidos en cada comunidad.

hipertensión arterial o valvulopatía, que el dispositivo implantado sea monocameral ventricular o que la implantación se realizase los últimos años de seguimiento parecieron favorecer la implantación de electrodos monobobina. De todas ellas la que más pareció influir en la elección del tipo de electrodo es el año en el que se realizó la implantación. De tal forma que por cada año transcurrido existe casi el doble de posibilidades de implantar un electrodo monobobina (OR, 1,86; IC95\%, 1,74-1,98; $\mathrm{p}<0,001)$.

\section{Datos recogidos en el momento de la implantación del desfibrilador}

En la tabla 3 se detallan los datos recogidos durante la implantación. Por un lado, es reseñable la baja tasa de complicaciones derivadas de la implantación de desfibriladores tanto en un grupo como en el otro, revistiendo en general poca gravedad las acontecidas y no existiendo fallecimientos derivados de la intervención.

Por otro lado, existen diferencias significativas entre el número de pacientes sometidos a protocolos de inducción al implante en favor de los electrodos bibobina. Sin embargo, esta apreciación queda matizada tras ajustarse según año de implantación. Así, la probabilidad de llevar a cabo un protocolo de inducción disminuyó un 33\% por cada año transcurrido (tabla 4). Por último, cabe señalar cómo durante dichos episodios de inducción, los umbrales fueron más bajos para los electrodos bibobina.

\section{Datos recogidos durante el seguimiento de los pacientes}

Durante el seguimiento de los pacientes (media y desviación estándar: $752,7 \pm 798,7$ días en los monobobina frente a $1.444,2 \pm 692,2$ días en los bibobina, $p<0,01$ ), se observó una baja incidencia de complicaciones (tabla 5). No obstante, destacaba una mayor proporción de choques en el grupo bibobina, de tal forma que un $17,5 \%$ de los pacientes de este grupo recibieron un choque durante el seguimiento. En cambio, solo el 5,8\% de los pacientes portadores de electrodos monobobina recibieron choques durante el seguimiento. La diferencia es claramente significativa entre ambos grupos $(p<0,001)$. Sin embargo, en gran medida, esta relación queda atenuada cuando se realiza un análisis ajustado por el año de implantación del desfibrilador, como puede apreciarse en la tabla 6. Por otro lado, es destacable la existencia de una mejor administración de terapias por parte de los desfibriladores monobobina, de forma que este grupo de pacientes recibió menos choques inapropiados $(17,03$ frente a $24,64 \%)$ siendo por tanto 
Tabla 1 - Características de la población en el momento de la implantación

\begin{tabular}{|c|c|c|c|}
\hline & $\begin{array}{l}\text { Monobobina } \\
(\mathrm{n}=535)\end{array}$ & $\begin{array}{l}\text { Bibobina } \\
(\mathrm{n}=3.596)\end{array}$ & $\mathrm{p}$ \\
\hline Edad (años) & $59,8 \pm 14,2$ & $61,5 \pm 13,3$ & 0,006 \\
\hline Sexo femenino & 19,2 & 17,8 & 0,412 \\
\hline Enfermedad renal crónica estadio con & 15,82 & 14,8 & 0,046 \\
\hline \multicolumn{4}{|l|}{ TFGe $<60\left(\mathrm{ml} / \mathrm{min} / 1,73 \mathrm{~m}^{2}\right)$} \\
\hline Diabetes mellitus & 29 & 27,9 & 0,612 \\
\hline Hipertensión arterial & 58,6 & 53,6 & 0,032 \\
\hline Tabaquismo & 37 & 37,5 & 0,820 \\
\hline Dislipidemia & 54,8 & 51,7 & 0,204 \\
\hline Historia familiar de muerte súbita & 8,2 & 9 & 0,531 \\
\hline Implantación en prevención primaria & 35,8 & 35,7 & 0,985 \\
\hline \multicolumn{4}{|l|}{ Proporción de pacientes según la FEVI } \\
\hline$>50 \%$ & 19,1 & 19,5 & \multirow[t]{4}{*}{0,126} \\
\hline $36-40 \%$ & 7,5 & 5,1 & \\
\hline $41-50 \%$ & 7,2 & 9,1 & \\
\hline$\leq 35 \%$ & 66,2 & 66,3 & \\
\hline Insuficiencia cardiaca & 65,7 & 66,8 & 0,591 \\
\hline \multicolumn{4}{|c|}{$\begin{array}{l}\text { Proporción de pacientes según clase funcional } \\
\text { de la NYHA (\%) }\end{array}$} \\
\hline I & 6,7 & 11,8 & \multirow[t]{4}{*}{0,226} \\
\hline II & 41,5 & 36,3 & \\
\hline III & 17,1 & 21,6 & \\
\hline IV & 34,7 & 30,5 & \\
\hline Anchura del QRS (ms) & $118 \pm 33,5$ & $121 \pm 34,6$ & 0,071 \\
\hline Cardiopatía isquémica & 48 & 50 & 0,404 \\
\hline Miocardiopatía dilatada no isquémica & 27,9 & 27,5 & 0,852 \\
\hline Miocardiopatía hipertrófica & 7,1 & 7,7 & 0,590 \\
\hline Miocardiopatía arritmogénica & 2,8 & 2 & 0,224 \\
\hline Valvulopatía & 8,2 & 4,8 & $<0,001$ \\
\hline Canalopatías & 3,5 & 4,9 & 0,179 \\
\hline Síndrome de Brugada & 3,2 & 3,4 & 0,749 \\
\hline Síndrome de QT largo & 0,4 & 1,3 & 0,057 \\
\hline Síndrome de QT corto & 0 & 0,02 & - \\
\hline TV catecolaminérgica & 0 & 0,1 & - \\
\hline
\end{tabular}

DE: desviación estándar, FEVI: fracción de eyección del ventrículo izquierdo, ms: milisegundos, NYHA: New York Heart Association, TFGe: tasa de filtrado glomerular estimada, TV: taquicardia ventricular.

Los datos expresan (\%) o media \pm desviación estándar

significativa esta diferencia ( $p=0,042$; OR terapia inapropiada para bibobina 1,58; IC95\%, 1,024-2,52).

\section{Discusión}

En nuestro estudio se observa cómo ha ido variando la implantación de electrodos de desfibrilación a lo largo de los últimos años, en favor de los electrodos monobobina, tanto de forma global como en la mayoría de regiones. Este cambio en la práctica habitual es concordante con lo descrito en otros estudios internacionales publicados con anterioridad ${ }^{9-11}$. No obstante, la principal novedad de nuestro estudio es que por primera vez podemos aproximarnos a la evolución de la práctica clínica de nuestro país. En este sentido se debe señalar que nuestro estudio se encuentra limitado al tratarse de un estudio observacional retrospectivo basado en un registro que recoge desfibriladores de una sola casa comercial (Medtronic). No obstante, es probable que los datos sean extrapolables a lo realizado con desfibriladores de otras casas comerciales. Otra limitación es que el volumen de información enviado por algunos hospitales es muy superior al de otros, lo que podría no representar de forma apropiada la práctica habitual de algunos centros. Además, no se conoce el grado de inclusión de pacientes realizado en los distintos hospitales, lo que dificulta la interpretación de los resultados, de forma aún más marcada en hospitales que han incluido pocos pacientes.

Cuando se analizan las características clínicas, así como determinados parámetros técnicos, se identifica cómo algunas variables se asocian de forma más intensa con la implantación de electrodos de desfibrilación monobobina. Así sucede con la mayor juventud de los pacientes, la hipertensión arterial, la presencia de valvulopatías, que el dispositivo implantado sea un desfibrilador monocameral o que la implantación se haya realizado en los últimos años. Los motivos por los que existe esta asociación con la hipertensión o la presencia de valvulopatías no están claros. Probablemente la asociación entre los desfibriladores automáticos implantables monocamerales y los electrodos monobobina esté al menos en parte relacionada con una coincidencia temporal que ha llevado los últimos años a la mayor implantación de desfibrilador automático implantable no bicameral ${ }^{1}$ y electrodos monobobina ${ }^{9-11}$. Finalmente, la asociación entre la menor edad de los pacientes que reciben electrodos monobobina 
Tabla 2 - Resultados de modelo de análisis univariante y multivariante en el que las odds ratio expresan la probabilidad de implantar electrodos monobobina

\begin{tabular}{|c|c|c|c|c|c|}
\hline \multirow[b]{2}{*}{ Variable } & \multirow[b]{2}{*}{ Categoría } & \multicolumn{2}{|c|}{ Análisis univariante } & \multicolumn{2}{|c|}{ Análisis multivariante } \\
\hline & & OR (IC95\%) & $\mathrm{p}$ & OR (IC95\%) & $\mathrm{p}$ \\
\hline Edad & & $0,991(0,98-0,99)$ & 0,006 & $0,98(0,97-0,99)$ & $<0,001$ \\
\hline \multirow[t]{2}{*}{ Sexo } & Varón & Ref. & & & \\
\hline & Mujer & $1,10(0,87-1,39)$ & 0,412 & $1,06(0,81-1,37)$ & 0,687 \\
\hline \multirow[t]{2}{*}{ HTA } & No & Ref. & & & \\
\hline & Sí & $1,22(1,02-1,48)$ & 0,032 & $1,39(1,12-1,74)$ & 0,004 \\
\hline \multirow[t]{2}{*}{ Valvulopatía } & No & Ref. & & & \\
\hline & Sí & $1,76(1,25-2,48)$ & $<0,001$ & $1,83(1,24-2,70)$ & 0,002 \\
\hline \multirow[t]{3}{*}{ Tipo dispositivo } & TRC-D & Ref. & & & \\
\hline & DAI-VR & $1,30(1,05-1,60)$ & $<0,001$ & $1,33(1,04-1,71)$ & 0,010 \\
\hline & DAI-DR & $0,75(0,57-0,99)$ & & $0,93(0,67-1,28)$ & \\
\hline \multirow[t]{4}{*}{ FEVI } & $<35 \%$ & Ref. & 0,126 & & 0,132 \\
\hline & $36-40 \%$ & $0,68(0,45-1,02)$ & & $0,71(0,46-1,11)$ & \\
\hline & $41-50 \%$ & $1,24(0,90-1,72)$ & & $1,22(0,84-1,77)$ & \\
\hline & $>50 \%$ & $1,02(0,81-1,29)$ & & $0,98(0,74-1,30)$ & \\
\hline \multicolumn{2}{|l|}{ Año implante } & $1,84(1,73-1,95)$ & $<0,001$ & $1,86(1,74-1,98)$ & $<0,001$ \\
\hline \multicolumn{6}{|c|}{$\begin{array}{l}\text { DAI-DR: desfibrilador automático implantable bicameral ventricular y auricular derechos; DAI-VR: desfibrilador automático implantable mono- } \\
\text { cameral ventricular; DAI-VR: desfibrilador automático implantable monocameral ventricular derecho; FEVI: fracción de eyección del ventrículo } \\
\text { izquierdo; HTA: hipertensión arterial; IC95\%: intervalo de confianza del 95\%; OR: odds ratio; Ref: variable de referencia; TRC-D: desfibrilador con } \\
\text { terapia de resincronización cardiaca. }\end{array}$} \\
\hline
\end{tabular}

Tabla 3 - Datos en el momento de la implantación del desfibrilador

\begin{tabular}{llll} 
& Monobobina $(\mathrm{n}=535)$ & Bibobina $(\mathrm{n}=3.596)$ & $\mathrm{p}$ \\
\hline Complicaciones (\%) & 3,5 & 2,7 & 0,270 \\
Muerte & 0 & 0 & - \\
Taponamiento & 0 & 0 & 0,056 \\
Neumotórax & 0.7 & 0,2 & 0,041 \\
Disección seno coronario & 0.7 & 0,2 & 0,124 \\
Situación subóptima & 1,7 & 53,5 & $<0,001$ \\
Inducción al implante & 20,6 & $17,57 \pm 5,7$ & $<0,001$ \\
Umbral desfibrilación al implante & $23,31 \pm 6,3$ & &
\end{tabular}

J: julios.

Los datos expresan (\%) o media \pm desviación estándar.

Tabla 4 - Probabilidad cruda y tras ajuste por el año de implantación de llevar a cabo inducción al implante

\begin{tabular}{|c|c|c|c|c|}
\hline & Variable & Categoría & OR (IC95\%) & $\mathrm{p}$ \\
\hline \multirow[t]{2}{*}{ Modelo univariante } & Tipo de electrodo & Bibobina & Ref. & \\
\hline & & Monobobina & $0,22(0,18-0,28)$ & $<0,001$ \\
\hline \multirow[t]{3}{*}{ Modelo multivariante } & Tipo de electrodo & Bibobina & Ref. & \\
\hline & & Monobobina & $0,48(0,38-0,62)$ & $<0,001$ \\
\hline & Año del implante & & $0,67(0,65-0,70)$ & $<0,001$ \\
\hline
\end{tabular}

pueda quizá atender a la ausencia de evidencia en favor de los electrodos bibobina ${ }^{2,3} \mathrm{y}$ al riesgo potencialmente mayor derivado del explante de este tipo de electrodos ${ }^{3,8}$, de forma que en los más jóvenes se les implante, como sucede en otros registros $^{9-11}$, aquel electrodo con menor riesgo de extracción.

El hecho de que en el grupo de pacientes a los que se les implantó electrodos bibobina se sometiese con más frecuencia a protocolos de inducción arrítmica, y de medición de umbrales de desfibrilación al implante, se encuentra muy relacionado con el momento en el que se implantó el electrodo: hace años se implantaban más electrodos bibobina $^{2,3}$ y se llevaban a cabo más test de inducción al implante ${ }^{1}$. Por el contrario, en la era más reciente se implantan más electrodos monobobina ${ }^{9-11}$ y apenas se realizan test de inducción durante la implantación ${ }^{1}$.

Por último, pueden existir varias razones que justifiquen en el grupo monobobina la menor proporción de choques durante el seguimiento, así como la mayor probabilidad de recibir choques apropiados en este mismo grupo. Probablemente la menor proporción de choques en los 
Tabla 5 - Complicaciones durante el seguimiento

\begin{tabular}{llll} 
& Monobobina $(\mathrm{n}=30)$ & Bibobina $(\mathrm{n}=537)$ & $\mathrm{p}$ \\
\hline Pacientes que reciben choques (\%) & 5,8 & 17,5 & $<0,001$ \\
$\quad$ Choques inapropiados (\%) & 17,03 & 24,64 & 1,7 \\
Muerte súbita cardiaca (\%) & 0 & 3,4 & - \\
Tormenta arrítmica (\%) & 0 & 0,2 & 0,616 \\
Arritmias auriculares (\%) & 0 & 0,2 & - \\
Bradiarritmias (\%) & 0 & 0,2 & - \\
Síncope (\%) & 0 & 0,7 & - \\
IAM (\%) & 3,3 & 19 & 0,239 \\
Descompensación de insuficiencia cardiaca (\%) & 33,3 & 1,9 & 0,055 \\
ACV/AIT (\%) & 0 & 1,5 & - \\
Infección del dispositivo (\%) & 0 & 0 & - \\
Disfunción del DAI (\%) & 0 & 0 & - \\
Estimulación frénica (\%) & 0 & 1,3 & - \\
Disfunción electrodo (\%) & 0 & -
\end{tabular}

ACV: accidente cerebrovascular; AIT: accidente isquémico transitorio; DAI: desfibrilador automático implantable; IAM: infarto agudo de miocardio.

Tabla 6 - Probabilidad cruda y tras ajuste por el año de implantación de recibir un choque durante el seguimiento en función del tipo de electrodo

\begin{tabular}{|c|c|c|c|c|}
\hline & Variable & Categoría & OR (IC95\%) & $\mathrm{p}$ \\
\hline \multirow[t]{2}{*}{ Modelo univariante } & Tipo de electrodo & Bibobina & Ref. & \\
\hline & & Monobobina & $0,29(0,20-0,42)$ & $<0,001$ \\
\hline \multirow[t]{3}{*}{ Modelo multivariante } & Tipo de electrodo & Bibobina & Ref. & \\
\hline & & Monobobina & $0,59(0,40-0,88)$ & 0,009 \\
\hline & Año del implante & & $0,73(0,70-0,76)$ & $<0,001$ \\
\hline
\end{tabular}

monobobina se encuentra estrechamente relacionada con el menor tiempo de seguimiento de este grupo. Además, los electrodos monobobina se han implantado más los últimos años, coincidiendo temporalmente con un cambio en la forma de programar los dispositivos, con el objeto de lograr una disminución en el número de terapias administradas ${ }^{12-14}$, atendiendo a las recomendaciones basadas en la evidencia más reciente, que relaciona las terapias con una mayor mortalidad $^{15,16}$ y la pérdida de calidad de vida de los pacientes $^{17,18}$.

\section{Conclusiones}

Como puede apreciarse en este estudio, parece que con los años, la práctica clínica con los desfibriladores ha ido cambiando, tanto en la forma de implantar como en la forma de programar estos dispositivos. En nuestro registro se observó un cambio en la elección del tipo de electrodo de desfibrilación, ya que fueron los electrodos monobobina los elegidos con más frecuencia a lo largo de los últimos años.

\section{Financiación}

El registro UMBRELLA está patrocinado por Medtronic. La investigación actual se ha nutrido de datos provenientes de dicho registro. Sin embargo, no se han recibido fondos económicos específicos, públicos o privados, para el presente estudio.

\section{Conflicto de intereses}

J. Martínez reconoce haber recibido honorarios y soporte no económico de Abbott y Medtronic. R. Villuendas reconoce haber recibido honorarios y soporte no económico de Medtronic y Johnson and Johnson. L. Pérez y N. Basterra reconocen haber recibido honorarios y soporte no económico de Abbott, Medtronic y Boston Scientific. Los autores previamente citados refieren que dichos conflictos de interés no interfieren con el presente trabajo. El resto de autores declaran no tener conflictos de interés en lo que se refiere a esta investigación.

\section{¿Qué se sabe del tema?}

Los últimos años, a nivel internacional, se aprecia un cambio en la implantación de electrodos de desfibrilación, de forma que los electrodos monobobina se están utilizando con más frecuencia.

En España no se dispone de información reciente acerca de lo acontecido con electrodos de desfibrilación. 


\section{¿Qué novedades aporta?}

Por primera vez disponemos de datos sobre la implantación de electrodos de desfibrilación en nuestro país. Los últimos años los electrodos monobobina son los más implantados.

En nuestro estudio, no se observaron diferencias clínicamente relevantes entre un tipo u otro de electrodo de desfibrilación. Este hecho puede favorecer la actual predilección por los electrodos monobobina, atendiendo fundamentalmente al mayor riesgo potencial durante la extracción de los electrodos bibobina.

\section{BIBLIOGRAF Í A}

1. Fernández Lozano I, Osca Asensi J, Alzueta Rodríguez J. Spanish Implantable Cardioverter-defibrillator Registry. 14th Official Report of the Spanish Society of Cardiology Electrophysiology and Arrhythmias Section (2017). Rev Esp Cardiol. 2018;71:1047-1058.

2. Aoukar PS, Poole JE, Johnson GW, et al. No benefit of a dual coil over a single coil ICD lead: Evidence from the sudden Cardiac Death in Heart Failure Trial. Heart Rhythm. 2013;10:970-976.

3. Kutyifa V, Huth Ruwald AC, Aktas MK, et al. Clinical impact Safety, and Efficacy of single- versus Dual-coil ICD Leads in MADIT-CRT. J Cardiovasc Electrophysiol. 2013;24:1246-1252.

4. Swerdlow CD, Davie S, Kass RM, et al. Optimal electrode configuration for pectoral transvenous implantable defibrillator without an active can. Am J Cardiol. 1995;76:370-374.

5. Gold MR, Foster AH, Shorofsky SR. Lead system optimization for transvenous defibrillation. Am J Cardiol. 1997;80:1163-1167.

6. Gold MR, Olsovsky MR, Pelini MA, Peters RW, Shorofsky SR. Comparison of single- and dual-coil active pectoral defibrillation lead systems. J Am Coll Cardiol. 1998;31:1391-1394.

7. Favale S, Dicandia CD, Tunzi P, Rizzon P. A prospective, randomized, comparison in patients between a pectoral unipolar defibrillation system and that using an additional inferior vena cava electrode. Pacing Clin Electrophysiol. 1999;22:1140-1155.

8. Shariff N, Alluri K, Saba S. Failure rates of single- Versus Dual-Coil Nonrecalled Sprint Quattro Defibrillator Leads. Am J Cardiol. 2015;115:202-205.
9. Hsu JC, Saxon LA, Jones PW, Wehrenberg S, Marcus GM. Utilization trends and clinical outcomes in patients implanted with a single- vs a dual-coil implantable cardioverter-defibrillator lead: Insights from the ALTITUDE Study. Heart Rhythm. 2015;12:1770-1775.

10. Leshem E, Suleiman M, Laish-Farkash A, et al. Contemporary rates and outcomes of single- vs. dual-coil implantable cardioverter defibrillator lead implantation: data from the Israeli ICD Registry. Europace. 2017;19:1485-1492.

11. Pokorney S, Parzynski C, Daubert J, et al. Temporal Trends in and Factors Associated with use of Single- Versus Dual-Coil Implantable Cardioverter-Defibrillator Leads Data from the NCDR ICD Registry. JACC Clin Electrophysiol. 2017;3:612-619.

12. Gasparini M, Menozzi C, Proclemer A, et al. A simplified biventricular defibrillator with fixed long detection intervals reduces implantable cardioverter defibrillator (ICD) interventions and heart failure hospitalizations in patients with non-ischaemic cardiomyopathy implanted for primary prevention: the RELEVANT [Role of long dEtection window programming in patients with LEft VentriculAr dysfunction Non-ischemic eTiology in primary prevention treated with a biventricular ICD] study. Eur Heart J. 2009;30:2758-2767.

13. Gasparini M, Proclemer A, Klersy C, et al. Effect of long-detection interval vs. standard detection interval for implantable cardioverter-defibrillators on antitachycardia pacing and shock delivery: The ADVANCE III randomized clinical trial. JAMA. 2013;309:1903-1911.

14. Wilkoff BL, Williamson BD, Stern RS, et al. Strategic programming of detection and therapy parameters in implantable cardioverter-defibrillators reduces shocks in primary prevention patients: Results from the PREPARE (Primary Prevention Parameters Evaluation) study. J Am Coll Cardiol. 2008;52:541-550.

15. Moss AJ, Schuger C, Beck CA, et al. Reduction in inappropriate therapy and mortality through ICD programming. N Engl J Med. 2012;367:2275-2283.

16. Saeed M, Hanna I, Robotis D, et al. Programming implantable cardioverter-defibrillators inpatients with primary prevention indication to prolong time to first shock: Results from the PROVIDE study. J Cardiovasc Electrophysiol. 2014;25:52-59.

17. Daubert JP, Zareba W, Cannom DS, et al. Inappropriate implantable cardioverter-defibrillator shocks in MADIT II: Frequency, mechanisms, predictors, and survival impact. J Am Coll Cardiol. 2008;51:1357-1365.

18. Van Rees JB, Borleffs CJ, de Bie MK, et al. Inappropriate implantable cardioverter-defibrillator shocks: Incidence, predictors, and impact on mortality. J Am Coll Cardiol. 2011;5:556-562. 


\section{Cáncer y desfibrilador automático implantable ¿causalidad, confusión o casualidad?}

Ignacio Roy ${ }^{\mathrm{a}}$, Lorena Malagon ${ }^{\mathrm{a}}$, Javier Martínez ${ }^{\mathrm{a}}$, Javier Romero ${ }^{\mathrm{a}}$, Aitziber Munarriz ${ }^{\mathrm{a}}$, Nuria Basterra $^{\mathrm{a}, \mathrm{b}}$.

(a) Cardiología, Área Clínica del Corazón, Complejo Hospitalario de Navarra, Pamplona, España. (b) Instituto de Investigación Sanitaria de Navarra (IdiSNA), Navarra, España.

\section{Resumen:}

Introducción y objetivos: el desfibrilador automático implantable (DAI) se ha establecido como terapia en pacientes con elevado riesgo de sufrir arritmias ventriculares malignas.

Algunos estudios plantean un posible efecto oncogénico de materiales protésicos utilizados. Igualmente, existen trabajos que describen mayor incidencia de cáncer en portadores de DAI y plantean una potencial relación causal entre ambos.

El objetivo principal del estudio es describir la incidencia de cáncer en nuestra muestra de pacientes portadores de DAI y compararla con resultados de otras bases de datos.

Métodos: estudio de cohortes retrospectivo de pacientes con DAI que se incluyeron en el Complejo Hospitalario de Navarra entre los años 2000 y 2016 y se siguieron hasta junio de 2018.

Se analizaron variables sociodemográficas, comorbilidades y datos sobre patología oncológica.

Se estimaron tasas de incidencia acumulada (TIA) de cáncer durante el seguimiento que se compararon con datos poblacionales y con datos de otra cohorte de pacientes con insuficiencia cardiaca con FEVI reducida. Se ajustaron modelos de riesgos competitivos para cáncer en el seguimiento.

Resultados: se incluyeron 497 pacientes, mayoritariamente hombres (89.1\%) con una edad media 59.98 (14.98) años, con una proporción de fumadores del 67.6\% y de cardiopatía isquémica del 51.6\%. La TIA de cáncer fue 1230.9 por 100.000 personas-año. Las variables que se asociaron significativamente con cáncer fueron mayor edad, mayor consumo de tabaco y cardiopatía isquémica. Conclusiones: la incidencia de cáncer es elevada en pacientes con DAI. Este hallazgo parece relacionado principalmente con el tabaco y la mayor edad.

\footnotetext{
Abstract:

Introduction and Objectives: implantable cardiac defibrillator (ICD) has been established as a therapy for malignant ventricular arrhythmias in patients at high risk of suffering them.

Some studies raise a possible relationship between the development of cancer and some prosthetic materials. Likewise, some investigations describe a higher incidence of cancer in patients with an
} 
ICD and that pose suggesting a potential relationship between both.

Methods: Retrospective cohort study of patients that underwent implantation of an ICD in the Complejo Hospitalario de Navarra between 2000 and 2016. The follow-up finished in June of 2018. Sociodemographic, comorbidities and oncologic data was analysed. Cancer incidence rates were estimated and compared with the general population data and with data of a cohort of patients with reduced LVEF heart failure. Risk of cancer models were adjusted by competitive risk models.

Results: 497 patients were included, mostly male (89.1\%), with a mean age of 59.98 (14.98) years and a proportion of smokers of $67.6 \%$ and of ischemic heart disease of $51.6 \%$. The cancer incidence rate in the sample was 1230.9 per 100.000 person-year. In our study, features associated with cancer were older age, higher tobacco use and ischemic cardiopathy.

Conclusions: In our sample of ICD carriers the incidence of cancer is high. This finding mainly seems to be related to tobacco usage and higher age.

Palabras clave: desfibrilador automático implantable (DAI), cáncer, oncología.

Key words: implantable cardiac defibrillator (ICD), cancer, oncology.

Tabla de abreviaturas: DAI: desfibrilador automático implantable; TIA: tasa de incidencia acumulada; EPOC: enfermedad pulmonar obstructiva crónica; DE: desviación estándar; SHR: subdistribución de la Hazard Ratio; IC: intervalo de confianza; FEVI: fracción de eyección del ventrículo izquierdo.

\section{Introducción y objetivos:}

El desfibrilador automático implantable (DAI) se ha establecido como terapia de la mayoría de pacientes recuperados de una parada cardiaca secundaria a una arritmia ventricular y como prevención primaria en pacientes con alguna condición clínica que implique mayor probabilidad teórica de sufrir arritmias ventriculares malignas ${ }^{1-3}$.

Trabajos publicados previamente plantean una posible relación entre el desarrollo de neoplasias y distintos materiales protésicos utilizados en la práctica clínica actual ${ }^{4-5}$. Igualmente, existen estudios que plantean una potencial relación entre el desarrollo de cáncer y dispositivos intracardiacos como marcapasos $^{6-8}$ y DAI $^{9-10}$. En este sentido, podría existir plausibilidad biológica, al haberse descrito en la literatura un potencial efecto oncogénico de algunos de los materiales que conforman un DAI ${ }^{11-15}$. La hipótesis del presente estudio es que la mayor incidencia de cáncer en pacientes con un DAI probablemente se encuentre más relacionada con una mayor prevalencia de factores de riesgo como el tabaquismo, claramente relacionados con el desarrollo de tumores ${ }^{18}$.

El objetivo principal de este estudio es describir la incidencia de cáncer en la cohorte de pacientes portadores de DAI de nuestro centro y compararla con otras bases de datos. El objetivo secundario es 
tratar de identificar factores relacionados con el desarrollo de cáncer en esta muestra de pacientes.

\section{Métodos:}

Estudio de cohortes retrospectivo elaborado a partir de la base de datos de pacientes portadores de DAI del Complejo Hospitalario de Navarra.

Se incluyeron todos los pacientes a los que se implantó un DAI en dicho centro entre enero del año 2000 y enero del año 2017. Se recogieron y actualizaron datos sobre enfermedad oncológica y mortalidad de la cohorte hasta el 30 de junio de 2018. La información se obtuvo de la Historia Clínica Informatizada del Servicio Navarro de Salud y se registró en una base de datos codificada y encriptada.

Los pacientes vivos firmaron un consentimiento informado que autoriza su seguimiento. Para los pacientes fallecidos se obtuvo una exención del consentimiento por parte de las autoridades competentes que a continuación se detallan, ante la relevancia clínica que supone el estudio y al considerarse imprescindible para la investigación el contar con la información de este grupo de pacientes. El presente trabajo cuenta con la autorización del Comité Ético de Investigación Clínica de Navarra, así como con el permiso del Departamento de Salud del Gobierno de Navarra.

Se recogieron variables sociodemográficas, comorbilidades entre las que se incluyen factores de riesgo para el desarrollo de cáncer, datos sobre el tipo de cardiopatía que justificaba la implantación de un DAI, información sobre la enfermedad oncológica de los pacientes y sobre mortalidad. El diagnóstico oncológico se basa en el resultado del estudio anatomopatológico reflejado en la Historia Clínica.

Se analizaron las características sociodemográficas y clínicas de los pacientes. Se estimaron las tasas de incidencia acumulada (TIA) de cáncer tanto de forma global como en determinados subgrupos a lo largo del seguimiento. Dichas TIA de cáncer se compararon con datos poblacionales provenientes de la Red Española de Registros de Cáncer (REDECAN) del año $2015^{16}$ y con datos de una cohorte de pacientes con insuficiencia cardiaca, con características demográficas (edad y sexo) similares a la de nuestra cohorte, pero en su mayoría no portadores de DAI ${ }^{17}$. Para la comparación con datos de REDECAN $^{16}$ se ajustaron las tasas de incidencia según edad y sexo en base a los datos poblacionales ofrecidos por el Instituto Nacional de Estadística Español (INE) ${ }^{19}$.

Finalmente se elaboraron modelos univariantes y multivariantes para identificar variables asociadas con el desarrollo de cáncer tras la implantación de un DAI, teniendo en cuenta entidades que puedan disminuir falsamente la incidencia de neoplasias al provocar el fallecimiento prematuro del paciente (insuficiencia cardiaca terminal, muerte arrítmica, accidente cerebrovascular, infecciones, otras causas de muerte no oncológica). 
Para llevar a cabo el análisis estadístico se ha utilizado el siguiente software: "SPSS Statistics v23”, "R v4.0.1” y “OpenEpi”. Para la comparación de variables categóricas (proporciones), se ha utilizado el test de Chi-cuadrado o su análogo no paramétrico (test exacto de Fisher). Para variables ordinales, se utilizó test de Chi-cuadrado de tendencia lineal. Para la comparación de variables continuas (medias), se ha recurrido a ANOVA, T-test o su análogo no paramétrico (test de Wilcoxon-MannWhitney) cuando no se pudo asumir la normalidad de la variable dependiente. Finalmente, para identificar variables asociadas con el desarrollo de neoplasias en el seguimiento, se ha elaborado un análisis basado en el modelo de riesgos competitivos de Fine-Gray.

\section{Resultados:}

\section{a) Participantes:}

Se incluyeron 497 pacientes que cumplían el criterio de elegibilidad al habérseles implantado un DAI en el Complejo Hospitalario de Navarra, durante el periodo de selección. Durante el seguimiento no hubo pérdidas y se analizó la información de todos ellos.

\section{b) Características basales de la muestra y sobre seguimiento:}

Como se observa en la tabla 1, la edad media es 59.98 (14.98) años, el 89.1\% son hombres, el 67.6\% ha sido fumador, manteniendo activo dicho hábito un 12.5\% y presentando EPOC un $15.5 \%$ del total de la muestra. El 51.7\% de los pacientes consumían alcohol, siendo este consumo "elevado" ( $\geq 70$ gramos/semana en hombres y $\geq 50$ gramos/semana en mujeres) en el 18.2\%.

La enfermedad cardiaca que justificaba el ser portador de un desfibrilador, en el $51.6 \%$ es la cardiopatía isquémica y en el $28.2 \%$ fue una miocardiopatía dilatada (MCD) no isquémica, siendo otro tipo de cardiopatías menos prevalentes.

Tabla 1. Características sociodemográficas y clínicas.

\begin{tabular}{|l|c|}
\hline Edad al implante del DA, años- media (DE) & $59.98(14.98)$ \\
\hline Sexo: hombres- $\mathrm{n}(\%)$ & $443(89.1)$ \\
\hline Seguimiento hasta fallecimiento o final del estudio, meses- media (DE) & $85(44.77)$ \\
\hline Tabaquismo- $\mathbf{n}(\%):$ & $156(31.4)$ \\
$\bullet \quad$ No fumador & $274(55.1)$ \\
$\bullet \quad$ Exfumador & $67(13.5)$ \\
\hline Duración tabaquismo, años- media (DE) & $37.71(12.40)$ \\
\hline
\end{tabular}




\begin{tabular}{|c|c|}
\hline Cigarrillos al día- media (DE) & 22.07 (11.99) \\
\hline Paquetes-año- media (DE) & $40.83(25.91)$ \\
\hline EPOC- n (\%) & $77(15.5)$ \\
\hline $\begin{array}{l}\text { Alcohol- } \mathrm{n}(\%) \text { : } \\
\begin{array}{l}\text { - No bebedor } \\
\text { - Bebedor: } \\
\circ \text { Ocasional/consumo leve } \\
\circ \text { Frecuente/consumo elevado }\end{array}\end{array}$ & $\begin{array}{l}228(48.3) \\
244(51.7) \\
158(33.5) \\
86(18.2)\end{array}$ \\
\hline $\begin{array}{l}\text { Tipo de cardiopatía- } \mathrm{n}(\%) \\
\text { - } \text { Cardiopatía isquémica } \\
\text { - MCD no isquémica } \\
\text { - Miocardiopatía hipertrófica } \\
\text { - Miocardiopatía arritmogénica } \\
\text { - Miocardiopatía restrictiva/infiltrativa } \\
\text { - Cardiopatía congénita }\end{array}$ & $\begin{array}{c}257(51.6) \\
149(28.2) \\
44(8.9) \\
25(5) \\
19(3.8) \\
7(1.4) \\
5(1)\end{array}$ \\
\hline
\end{tabular}

EPOC: enfermedad pulmonar obstructiva crónica; MCD: miocardiopatía dilatada; Bebedor frecuente/consumo enólico elevado: $\geq 70$ gramos/semana en hombres y $\geq 50$ gramos/semana en mujeres; DE: desviación estándar.

Las variables cuantitativas se presentan como medias con su correspondiente desviación estándar (DE). Las variables cualitativas se muestran como número (n) y proporción (\%).

El $8.9 \%$ de los pacientes tenían historia oncológica previa a la implantación del DAI, siendo los tumores más frecuentes los prostáticos, vesicales, colónicos, faríngeos/laríngeos y hematológicos (tabla 2).

Tabla 2. Datos oncológicos.

\begin{tabular}{|l|c|c|}
\hline Localización del tumor - n (\%) & Antes del DAI (8.9\%) & Después del DAI (15.3\%) \\
\hline Próstata & $8(18.2)$ & $16(21.1)$ \\
Vejiga & $10(22.7)$ & $14(18.4)$ \\
Renal & $0(0)$ & $2(2.6)$ \\
Pulmón & $1(2.3)$ & $10(13.2)$ \\
Laringe/faringe & $3(6.8)$ & $4(5.3)$ \\
Colon & $5(11.4)$ & $11(14.5)$ \\
Esófago/estómago & $0(0)$ & $2(2.6)$ \\
Hepatobiliopancreático & $4(9.1)$ & $2(2.6)$ \\
Cutáneo “no melanoma" & $2(4.5)$ & $4(5.3)$ \\
Melanoma & $0(0)$ & $2(2.6)$ \\
Hematológico & $4(9.1)$ & $3(3.9)$ \\
Mama & $1(2.3)$ & $1(1.3)$ \\
\hline
\end{tabular}




\begin{tabular}{|l|c|c|}
\hline Tiroides & $1(2.3)$ & $0(0)$ \\
Sarcoma de partes blandas & $1(2.3)$ & $4(1.3)$ \\
Otros tumores (neurinoma acústico, & $2(4.5)$ & $0(0)$ \\
glioma, Warthin, etc) & $2(4.5)$ & $46(60.8)$ \\
Varios tumores “metacrónicos" & $25(54.3)$ & \\
\hline Tumor relacionado con tabaco (\%) & & $7.80(10.45)$ \\
\hline
\end{tabular}

DE: desviación estándar.

Las variables cuantitativas se presentan como medias con su correspondiente desviación estándar (DE). Las variables cualitativas se muestran como número (n) y proporción (\%).

Hubo datos ausentes en algunas de las variables secundarias, pero en ningún caso dicha pérdida supuso más del 5\% de la información de una variable. En las variables de mayor interés (cáncer o mortalidad) no hubo datos ausentes. No se aplicaron métodos de imputación.

El seguimiento medio de la cohorte fue de 85 (44.77) meses.

\section{c) Datos sobre mortalidad:}

Durante el seguimiento, fallecieron el 35\% de los pacientes, con una edad media de 71.93 (10.53) años. La causa más frecuente del exitus fue la cardiaca (46\%), siendo más frecuente la muerte por insuficiencia cardiaca (39.1\%) que por arritmias (6.9\%). La siguiente etiología en frecuencia fue la enfermedad oncológica (16.1) (tabla 3).

Tabla 3. Datos sobre mortalidad.

\begin{tabular}{|l|c|}
\hline Exitus - n (\%) & $174(35)$ \\
\hline Edad exitus, años - media (DE) & $71.93(10.53)$ \\
\hline $\begin{array}{l}\text { Tiempo medio transcurrido desde el implante del DAI hasta el Exitus, } \\
\text { años - media (DE) }\end{array}$ & $4.84(3.17)$ \\
\hline Causas de Exitus - n (\%): & \\
- Insuficiencia cardiaca & $68(39.1)$ \\
- Muerte arrítmica & $12(6.9)$ \\
- Cáncer & $28(16.1)$ \\
- Accidente cerebrovascular & $9(5.2)$ \\
- Infección & $25(14.4)$ \\
- Otras (cirrosis, isquemia mesentérica, etc) & $16(9.2)$ \\
\hline
\end{tabular}



muestran como número (n) y proporción (\%).

\section{d) Datos sobre enfermedad oncológica en la muestra:}

A lo largo del seguimiento el $15.3 \%$ desarrolló neoplasias tras la implantación del DAI, estando el $60.8 \%$ de ellas relacionadas con el tabaco ${ }^{13}$. Fueron responsables del fallecimiento de un $5.6 \%$ del total de pacientes. El tiempo medio entre el implante del DAI y la aparición de cáncer fue de 4.84 (3.17) años. Los tumores más frecuentes fueron similares en su mayoría a los desarrollados antes de la implantación del DAI (próstata, vejiga, colon y faríngeos/laríngeos), salvo por la mayor incidencia de cáncer de pulmón y por la menor incidencia de neoplasias hepatobiliopancreáticas y hematológicas (tabla 3).

La TIA acumulada de cáncer de nuestra muestra ajustada por edad a la de la población de referencia es 1230.9 por cada 100.000 personas-año. Esta tasa es significativamente mayor $(\mathrm{p}<0.001)$ en los pacientes fumadores (1382.2 por cada 100.000 personas-año) o con cardiopatía isquémica (1563.3 por cada 100.000 personas-año) y es significativamente menor $(\mathrm{p}<0.001)$ en pacientes no fumadores (587.5 por cada 100.000 personas-año) o con cardiopatías de etiología no isquémica (666.3 por cada 100.000 personas-año).

La TIA poblacional ofrecida por la Red Española de Registros de Cáncer (REDECAN) del año $2015^{12}$ (653.1 casos por cada 100.000 personas-año), es significativamente menor $(\mathrm{P}<0.001)$ que la global ajustada por edad de nuestra muestra y que la de subgrupos de más riesgo como fumadores o pacientes con cardiopatía isquémica, siendo similar a la de pacientes no fumadores o sin cardiopatía isquémica. La TIA recientemente publicada en una cohorte española de pacientes con insuficiencia cardiaca con FEVI reducida, en la que solamente el $20.4 \%$ eran portadores de DAI, es 1288.6 casos por 100.000 personas-año ${ }^{13}$. Dicha tasa es muy similar a la que encontramos en el conjunto de nuestros pacientes portadores de DAI.

\section{e) Variables asociadas con el desarrollo de cáncer tras la implantación de DAI:}

Las variables asociadas significativamente con el desarrollo de cáncer tras la implantación de un DAI, tras llevar a cabo un ajuste por causas de muerte distintas de la enfermedad oncológica posterior a la implantación del DAI, que puedan competir con el desarrollo de neoplasias, son la mayor edad (sHR 1.04 IC95\% 1.02-1.06), el mayor consumo de cigarrillos al día (sHR 1.02 IC95\% 1.00-1.03) y la presencia de cardiopatía isquémica (sHR 1.22 IC95\% 1.12-1.34) (tabla 4). 
Tabla 4. Modelo de riesgos competitivos de Fine-Gray para el desarrollo de cáncer tras la implantación de un DAI.

\begin{tabular}{|c|c|c|c|c|c|}
\hline & & \multicolumn{2}{|c|}{ Univariante } & \multicolumn{2}{|c|}{ Multivariante } \\
\hline \multicolumn{2}{|l|}{ Variable } & SHR (IC95\%) & P valor & SHR (IC95\%) & P valor \\
\hline \multicolumn{2}{|l|}{ Edad } & $1.04(1.02,1.06)$ & $<0.001$ & $1.04(1.02-1.06)$ & $<0.001$ \\
\hline \multirow{2}{*}{ Sexo } & Mujer & Ref. & \multirow{2}{*}{0.190} & Ref. & \multirow{2}{*}{0.520} \\
\hline & Hombre & $1.84(0.73-4.59)$ & & $1.39(0.52-3.73)$ & \\
\hline \multicolumn{2}{|c|}{ Número cigarrillos/día } & $1.02(1.01-1.03)$ & 0.001 & $1.02(1.00-1.03)$ & 0.038 \\
\hline \multirow{2}{*}{$\begin{array}{l}\text { Cardiopatía } \\
\text { isquémica }\end{array}$} & No & Ref. & \multirow{2}{*}{$<0.001$} & Ref. & \multirow{2}{*}{$<0.001$} \\
\hline & Sí & $1.32(1.17-1.48)$ & & $1.22(1.12-1.34)$ & \\
\hline \multirow{2}{*}{ Cáncer previo } & No & Ref. & \multirow{2}{*}{0.840} & Ref. & \multirow{2}{*}{0.630} \\
\hline & Sí & $1.09(0.49-2.40)$ & & $0.81(1.23-1.89)$ & \\
\hline
\end{tabular}

SHR: sub-distribución de la Hazard Ratio; IC95\%: intervalo de confianza al 95\%; Ref: variable tomada como referencia para las comparaciones.

\section{Discusión}

Existen grupos que plantean una potencial relación causa-efecto entre el DAI y el desarrollo de cáncer $^{9-10}$. Nuestra hipótesis es que dicha relación se basa principalmente en la coexistencia de determinados factores y marcadores de riesgo que se asocian tanto con el desarrollo de neoplasias como con determinadas cardiopatías y eso podría explicar la mayor incidencia de cáncer en pacientes portadores de un DAI.

En este sentido, tal y como se aprecia en el presente estudio y como sucede en otros registros de pacientes portadores de un $\mathrm{DAI}^{20} \mathrm{o}$ en registros de pacientes con insuficiencia cardiaca con FEVI reducida $^{17}$, aproximadamente la mitad de los pacientes tienen antecedentes personales de cardiopatía isquémica, lo que a su vez se asocia con la mayor edad, el sexo masculino y la elevada prevalencia de tabaquismo observadas. Igualmente, se observa una elevada proporción de muertes durante el seguimiento, cuestión consistente con otros estudios que incluyen cardiopatías en general avanzadas $^{17,21-22}$.

Cuando analizamos datos oncológicos de nuestros pacientes destaca la elevada TIA de cáncer, muy superior a la poblacional utilizada como comparador ${ }^{16}$, pero similar a la observada en una cohorte de pacientes españoles, con insuficiencia cardiaca con FEVI reducida, en su mayoría no portadores de un $\mathrm{DAI}^{17}$. Por otro lado, cuando estratificamos la muestra en función de la historia de tabaquismo y de cardiopatía isquémica, la TIA de los paciente no fumadores y no isquémicos son muy similares a las de la poblacional general ${ }^{16}$. Esta relación se confirma en los modelos univariantes y multivariantes ajustados por riesgos competitivos, que muestran mayor riesgo oncológico entre los pacientes de edad más avanzada, más fumadores y con cardiopatía isquémica. 
Las observaciones previas apuntan hacia cómo determinadas características (edad avanzada, tabaquismo, etc.) más prevalentes en cohortes de pacientes portadores de $\mathrm{DAI}^{10,20}$ o con insuficiencia cardiaca con FEVI reducida ${ }^{17}$ pueden ser los principales responsables de la mayor incidencia de cáncer en estos grupos de pacientes, lo que estaría en consonancia con nuestra hipótesis que asocia la mayor incidencia de cáncer de los pacientes portadores de DAI con dichos factores y no con el DAI. La extrapolación de los resultados de este estudio a la población general parece razonable dado que la fuente es una base de datos del único hospital terciario de referencia para la Comunidad Foral de Navarra, que por tanto atiende a la inmensa mayoría de esta población, independientemente de su edad, sexo o estrato socioeconómico.

La principal limitación del estudio es la ausencia en la muestra de pacientes no portadores de DAI. Ello impide realizar comparaciones directas, habiendo tenido que recurrir a datos de registros externos $^{16-17}$.

Otra limitación inherente al presente estudio es el reducido tamaño de la cohorte y el tiempo acumulado de seguimiento de la misma, que en caso de ser mayores permitirían detectar más casos incidentes de cáncer.

\section{Conclusiones}

Los pacientes portadores de DAI presentan una incidencia de cáncer mayor que la de la población general, pero similar a la de una cohorte contemporánea de pacientes con insuficiencia cardiaca con FEVI reducida, mayoritariamente no portadores de un DAI. Tabaco y edad parecen influir de forma significativa en el desarrollo de neoplasias. Sin embargo, no se puede descartar la relación causal entre DAI y cáncer.

\section{Conflictos de interés:}

El Dr. Martínez, el Dr. Romero y la Dra. Munárriz reconocen haber recibido honorarios y soporte no económico de Abbot y Medtronic. La Dra. Basterra reconoce haber recibido honorarios y soporte no económico de Abott, Medtronic y Boston Scientific. Los autores previamente citados refieren que dichos conflictos de interés no interfieren con el presente trabajo. El resto de autores declaran no tener conflictos de interés en lo que se refiere a esta investigación.

\section{Financiación del estudio:}

No se han recibido fondos económicos públicos o privados, para llevar a cabo este estudio. 


\section{Bibliografía:}

1. Priori S, Blomstrom-Lundqvist C, Mazzanti A. et al. 2015 ESC Guidelines for the management of patients with ventricular arrhythmias and the prevention of sudden cardiac death. European Heart Journal. 2015; 36: 2793-2867.

2. Epstein AE, DiMarco JP, Ellenbogen KA et al. ACC/AHA/HRS 2008 Guidelines for DeviceBased Therapy of CardiacRhythm abnormalities: A Report of the American College of Cardiology/American Heart Association Task Force on Practice Guidelines (Writing Committee to Revise the ACC/AHA/NASPE 2002 Guideline Update for Implantation of Cardiac Pacemakers and Antiarrhythmia Devices): Developed in Collaboration with the American Association for Thoracic Surgery and Society of Thoracic Surgeons. Circulation. 2008; 117:e350-408.

3. Moss AJ, Hall WJ, Cannom DS, et al. Improved survival with an implanted defibrillator in patients with coronary disease at high risk for ventricular arrhythmia. N Engl J Med. 1996;335: 1933-40.

4. Wagner P, Olsson H, Lidgren L, et al. Increased cancer risks among arthroplasty patients: 30-year follow-up of the Swedish Knee Arthroplasty Register. Eur J Cancer. 2011; 47:1061-71.

5. de Jong D, Vasmel WL, de Boer JP, et al. Anaplastic large-cell lymphoma in women with breast implants. JAMA. 2008; 300:20302035.

6. Liao JN, Chen IM, Yang AH, Yu WC. A primary cardiac sarcoma spreading along the pacing leads of a permanent pacemaker. J Am CollCardiol. 2012; 59:1487.

7. Reyes CV. Clear cell hidradenocarcinoma developing in pacemaker pocket. Pacing ClinElectrophysiol. 2008; 31:15131615.

8. Lipworth L, Johansen C, Arnsbo P, et al. Cancer risk among pacemaker recipients in Denmark, 1982-1996. J Long Term Eff Med Implants. 2002; 12:263-270.

9. Nayar V, Wright P, Pugh PJ. Recurrence of B-cell lymphoma within an implantable cardioverter defibrillator wound scar. Europace. 2011; 13:443-444.

10. Pedersen S, Nielsen J, Bøtker H, et al. Implantable cardioverter-defibrillators and subsequent cancer risk: a nationwide population-based cohort study. Europace. 2015; 17:902-908.

11. Keegan GM, Learmonth ID, Case CP. A systematic comparison of the actual, potential, and theoretical health effects of cobalt and chromium exposures from industry and surgical implants. Crit Rev Toxicol. 2008; 38: 645-674.

12. DeMatteo R, Keith M.M, Brophy J.T, et al. Chemical exposures of women workers in the plastics industry with particular reference to breast cancer and reproductive hazards. New Solut. 2012; 22:427-448.

13. Diamanti-Kandarakis E, Bourguignon J.P, Giudice L.C, et al. Endocrine-disrupting chemicals: an Endocrine Society scientific statement. Endocr Rev. 2009; 30:293-342. 
14. Tarapore P, Ying J, Ouyang B, et al. Exposure to bisphenol A correlates with early-onset prostate cancer and promotes centrosome amplification and anchorage-independent growth in vitro. PLoS One. 2014; 9:e90332.

15. Konieczna A, Rutkowska A, Rachoń D. Health risk of exposure to Bisphenol A (BPA). Rocz Panstw Zakl Hig. 2015; 66:5-11.

16. Galceran J, Amejide, Carulla M, et al. Cancer incidence in Spain, 2015. ClinTrans1Oncol. 2017 Jul; 19:799-825.

17. Martínez-Mateo V, Fernández-Anguita M, Cejudo L, et al. Incidence of cancer in patients with heart failure and reduced ejection fraction. REC Cardioclinics. 2019; 54:247-252.

18. Sasco A.J, Secretan M.B, Straif K. Tobacco smoking and cancer: a brief review of recent epidemiological evidence. Lung Cancer. 2004; 45:S3-9.

19. https://www.ine.es/jaxi/Datos.htm?path=/t20/e245/p08/10/\&file=02002.px\#!tabs-tabla

20. Fernández Lozano I, Osca Asensi J, Alzueta Rodríguez J. SpanishImplantableCardioverterdefibrillatorRegistry. 14th Official Report of the Spanish Society of Cardiology Electrophysiology and Arrhythmias Section (2017). Rev EspCardiol. 2018; 7:1047-1058.

21. Normand SL, Wang Y, Krumholz HM. National and regional trendsin heart failure hospitalization and mortality rates for Medicare beneficiaries, 1998-2008. JAMA. 2011; 306:1669-1678.

22. Pons F, Lupón J, Urrutia A, et al. Mortality and Cause of Death in Patients with Heart Failure: Findings at a Specialist Multidisciplinary Heart Failure Unit. Rev EspCardiol. 2010; 63:303-314. 


\section{Apéndice:}

Carta de aceptación para la publicación en la revista "Medicina Clínica" del artículo "Cáncer y desfibrilador automático implantable ¿causalidad, confusión o casualidad?”

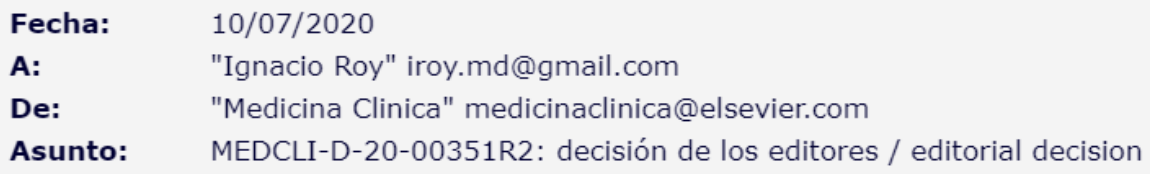

Apreciado/a Sr. Roy:

Nos es grato comunicarle que el Comité de Redacción de Medicina Clínica ha aceptado el artículo "Cáncer y desfibrilador automático implantable, ¿̇causalidad, confusión o casualidad?" (Ref. MEDCLI-D-2000351R2) que Ud. nos envió para su publicación en la misma .

Recuerde que en su momento le remitiremos las pruebas de autor en formato pdf a esta misma dirección electrónica.

Sin otro particular, reciba un cordial saludo.

Comité Editorial

Medicina Clínica

Dear Sr. Roy,

We are glad to inform you that your article "Cáncer y desfibrilador automático implantable, ¿causalidad, confusión o casualidad?" (Ref. MEDCLI-D-20-00351R2) has been accepted for its publication in Medicina Clínica.

Please remember that, before publication, you will receive an e-mail with the galley proofs of your article in pdf format.

Thank you for your contribution to the journal.

Yours sincerely,

\section{Factor de impacto de las Revistas que han publicado o aceptado para su publicación los artículos recogidos en la tesis:}

- REC Cardioclinics año 2019: aún no cuenta con factor de impacto. No obstante, es una publicación oficial de la Sociedad Española de Cardiología que se engloba en la familia de publicaciones de la Revista Española de Cardiología. Es una revista científica internacional, de periodicidad trimestral. Se encuentra indexada (ScienceDirect, Scopus y 
Latindex): CiteScore de 2019 0,3; SJR 0.104; SNIP 0,053. Se adhiere a las normas del Comité Internacional de Editores de Revistas Médicas y a las directrices del Committee on Publication Ethics.

- Medicina Clínica, factor de impacto del año 2019: 1,635.

\section{Áreas temáticas correspondientes a las publicaciones que se recogen en la tesis:}

- Cardiología.

- Arritmias y estimulación cardiaca.

- Desfibrilador automático implantable.

- Electrodos de desfibrilación.

- Oncología.

\section{Contribución del doctorando (trabajos en coautoría):}

1. Evolución temporal en la implantación de electrodos de desfibrilación monobobina o bibobina en nuestro país. Datos de un gran registro español.

- El doctorando recibió la base de datos del Registro multicéntrico UMBRELLA, tras proponer el proyecto de investigación y ser aceptado por el Comité encargado (Proyecto SCOOP). Los documentos referentes a cuestiones legales o bioéticas (consentimiento informado, aceptación por parte del Comité Ético de Investigación Clínica del Hospital Puerta de Hierro, etc) ya habían sido tramitados por el Comité del Proyecto SCOOP.

- El análisis estadístico fue realizado por parte del doctorando, bajo la supervisión de la Unidad de Metodología Apoyo a la investigación del Centro de Investigación Biomédica Navarrabiomed.

- La redacción del artículo y el proceso editorial hasta lograr la publicación fue llevada a cabo por el doctorando, bajo la colaboración del resto de coautores.

2. Cáncer y desfibrilador automático implantable ¿causalidad, confusión o casualidad?

- El doctorando elaboró un proyecto de investigación que fue autorizado por el Departamento de Salud del Gobierno de Navarra y cuenta con la aprobación del Comité Ético de Investigación Clínica de Navarra.

- La base de datos fue recogida por la Dra. Lorena Malagón y el doctorando. 
- El análisis estadístico fue realizado por parte del doctorando, bajo la supervisión de la Unidad de Metodología Apoyo a la investigación del Centro de Investigación Biomédica Navarrabiomed.

- La redacción del artículo y el proceso editorial hasta lograr la publicación fue llevada a cabo por el doctorando, bajo la colaboración del resto de coautores. 